\title{
Preventive Effects of Rhodiola rosea L. on Bleomycin-Induced Pulmonary Fibrosis in Rats
}

\author{
Ke Zhang ${ }^{1}$, Xiao-Ping $\mathrm{Si}^{2}$, Jian Huang ${ }^{1, *}$, Jian Han ${ }^{1}$, Xu Liang $^{3}$, Xiao-Bo Xu ${ }^{1}$, Yi-Ting Wang ${ }^{3}$, \\ Guo-Yu Li ${ }^{3}$, Hang-Yu Wang ${ }^{3}$ and Jin-Hui Wang ${ }^{1,3, *}$ \\ 1 School of Traditional Chinese Materia Medica, Shenyang Pharmaceutical University, \\ Shenyang 110016, China; xjzk1984@163.com (K.Z.); 13998302950@163.com (J.H.); \\ xxb517234556@sina.com (X.-B.X.) \\ 2 Shihezi Institute for Drug Control, Shihezi 832002, China; shz_yjs@sina.com \\ 3 College of Pharmacy, Shihezi University, Shihezi 832002, China; lix8182@163.com (X.L.); \\ christina.wyt@foxmail.com (Y.-T.W.); liguoyulisa@163.com (G.-Y.L.); why_pha@shzu.edu.cn (H.-Y.W.) \\ * Correspondence: profhj@163.com (J.H.); profwjh@126.com (J.-H.W.); Tel.: +86-24-2398-6479 (J.H. \& J.-H.W.) \\ Academic Editor: Sanjay K. Srivastava \\ Received: 30 March 2016; Accepted: 24 May 2016; Published: 3 June 2016
}

\begin{abstract}
Rhodiola rosea L. (RRL) possesses a wide range of pharmacological properties, including lung-protective activity, and has been utilized in folk medicine for several 100 years. However, the lung-protective mechanism remains unclear. This study investigated the possible lung-protective activity mechanism of RRL in a pulmonary fibrosis (PF) rat model. Lung fibrotic injury was induced in Sprague-Dawley rats by single intratracheal instillation of saline containing bleomycin (BLM; $5 \mathrm{mg} / \mathrm{kg}$ ). The rats were administered 125,250 , or $500 \mathrm{mg} / \mathrm{kg}$ of a $95 \%$ ethanol extract of RRL for 28 days. The animals were killed to detect changes in body weight, serum levels of glutathione (GSH) and total superoxide dismutase (T-SOD), as well as lung tissue hydroxyproline (HYP) content. Tumor necrosis factor- $\alpha$ (TNF- $\alpha$ ), transforming growth factor- $\beta 1$ (TGF- $\beta 1$ ), and interleukin 6 (IL-6) levels were measured in bronchoalveolar lavage fluid (BALF) by enzyme-linked immunosorbent assay. Hematoxylin and eosin, Masson's trichrome, and immunohistochemical staining were performed to observe the histopathological changes in lung tissues. Additionally, target-related proteins were measured by Western blotting. RRL alleviated the loss of body weight induced by instilling BLM in PF rats, particularly at the $500 \mathrm{mg} / \mathrm{kg}$ per day dose. RRL reduced HYP $(p<0.01)$ and increased GSH and T-SOD contents. BALF levels of TNF- $\alpha$, TGF- $\beta 1$, and IL- 6 decreased significantly in the RRL-treated groups. Expression levels of matrix metalloproteinase-9 (MMP-9) and $\alpha$-smooth muscle actin decreased significantly in a dose-dependent manner in response to RRL. Moreover, the levels of TGF- $\beta 1$ and tissue inhibitor of metalloproteinase- 1 in lung tissues also decreased in the RRL-treated groups. RRL alleviated BLM-induced PF in rats. Our results reveal that the protective effects of RRL against fibrotic lung injury in rats are correlated with its anti-inflammatory, antioxidative, and anti-fibrotic properties. MMP-9 may play important roles in BLM-induced PF.
\end{abstract}

Keywords: Rhodiola rosea L.; pulmonary fibrosis; bleomycin; TGF- $\beta 1$; MMP-9

\section{Introduction}

Pulmonary fibrosis (PF) is a progressive interstitial lung disease characterized by excessive proliferation of fibroblasts and deposition of collagens and other extracellular matrix (ECM) proteins [1]. $\mathrm{PF}$ is induced by a variety of etiological factors, including inflammation, the epithelial-mesenchymal transition (EMT), oxidative stress, and immune dysfunction, which result in alveolar epithelial cell injury, and fibroblast proliferation that consequently lead to abnormal deposition of the extracellular matrix (ECM) and tissue remodeling. A balanced turnover of the ECM through regulation of 
myofibroblast synthesis and degradation by matrix metalloproteinases (MMPs) is critical for proper formation. This process is featured by the presence of $\alpha$-smooth muscle actin ( $\alpha$-SMA) and high synthetic rates of ECM components including collagens [2]. MMPs and tissue inhibitors of metalloproteinases (TIMPs) comprise an important enzyme system that regulates degradation of the cellular matrix. Shan-Zhong Tan et al. [3] suggested that MMPs and TIMPs are involved in degradation of the ECM and basement membrane during early PF (injury stage), whereas they play an important role regulating remodeling of lung tissue structure in the late stages of PF. Many factors change the expression of MMPs, including pro-inflammatory cytokines, such as tumor necrosis factor- $\alpha$ (TNF- $\alpha$ ) and interleukin-6 (IL-6), which increase during the early phase of PF and are essential in the progression of early pulmonary inflammation to PF [4,5]. These changes have been associated with increased MMP levels [6] and induction of MMP production from various cell types, including alveolar epithelial cells, alveolar fibroblasts, and alveolar macrophages [7-9]. Some studies have also shown that other cytokines, such as transforming growth factor- $\beta 1$ (TGF- $\beta 1$ ), regulate MMP-9 and TIMP-1 expression, suggesting that these cytokines may play roles in pulmonary cells and promote PF through synergistic actions with TGF- $\beta 1$. However, the PF mechanism is not completely understood, and novel therapeutic agents to treat $\mathrm{PF}$ are still needed.

Rhodiola rosea L. (RRL; Crassulaceae family), also known as golden root or rose root, has a long history as traditional Chinese medicine (TCM) with medicinal efficacy similar to that of ginseng and Many prickle Acathopanax roots. RRL is a perennial herbaceous plant widely distributed at high altitudes on rocks and on Arctic sea cliffs in Europe, Asia, and North America [10]. The dried roots and rhizomes of RRL are called Hong-Jing-Tian in Chinese [11] and are traditionally used as a tonic and adaptogen in TCM and as a hemostatic in Tibetan folk medicine. The pharmacological effects of RRL preparations are attributed to the phenylpropanoids, organic acids, and flavonoids extracted from the roots and rhizomes. RRL preparations exhibit adaptogenic effects, including neuroprotective, cardioprotective, anti-fatigue, anti-depressive, anxiolytic [12], nootropic, hepatoprotective, anti-allergic, anti-cancer, and life-span increasing effects, as well as central nervous system stimulating [13-15], anti-nociceptive, and anti-inflammatory activities [16,17]. These earlier studies mainly focused on the anti-inflammatory and anti-apoptotic/pro-apoptotic effects of salidroside in lung tissues and/or cells but not on its anti-fibrotic potential. One previous study revealed a novel anti-fibrotic effect of salidroside in the liver [18], which prompted us to investigate whether it is also effective in alleviating fibrotic lung injury. Thus, the aim of the present study was to investigate the anti-fibrotic effect and possible mechanism of an RRL extract on bleomycin (BLM)-induced PF in rats.

\section{Results}

\subsection{RRL Mitigates Inflammation in Rats with BLM-Induced Pulmonary Fibrosis}

To determine the effect of RRL on the BLM-induced pulmonary inflammatory response in rats, levels of the inflammatory cytokines TGF- $\beta 1$, TNF- $\alpha$, and IL- 6 were determined in BALF. As a result, TGF- $\beta 1$, TNF- $\alpha$, and IL- 6 protein levels in BALF of the model group increased significantly after 28 days compared with those in the normal group $(p<0.01)$, whereas these levels in the treatment group were significantly lower than those in the model group after 28 days $(p<0.01)$ (Figure 1$)$. These data show that the RRL treatment lowered levels of the TGF- $\beta 1$, TNF- $\alpha$, and IL- 6 proteins in BALF, indicating that RRL has anti-inflammatory properties in rats with BLM-induced lung fibrosis.

\subsection{RRL Alleviates Pathological Changes}

$\mathrm{H} \& \mathrm{E}$ and Masson's trichrome staining were applied to confirm establishment of the BLM-induced PF rat model. The $\mathrm{H} \& \mathrm{E}$ results after 28 days showed normal pulmonary alveoli in the normal group and no pathological changes, such as alveolitis or interstitial pulmonary fibrosis. Severe PF was observed in lungs from the BLM group (Figure 2), including marked thickening of alveolar septa, collapsed alveolar spaces, loss of alveolar structure, and over-proliferation of fibroblasts. The model 
group showed predominant infiltration of mononuclear cells rather than accumulation of neutrophils in the alveolar compartment. The $125 \mathrm{mg} / \mathrm{kg}$ RRL treatment slightly ameliorated the BLM-induced pathological changes in the lungs, whereas the 250 and $500 \mathrm{mg} / \mathrm{kg}$ RRL doses significantly alleviated BLM-induced PF.

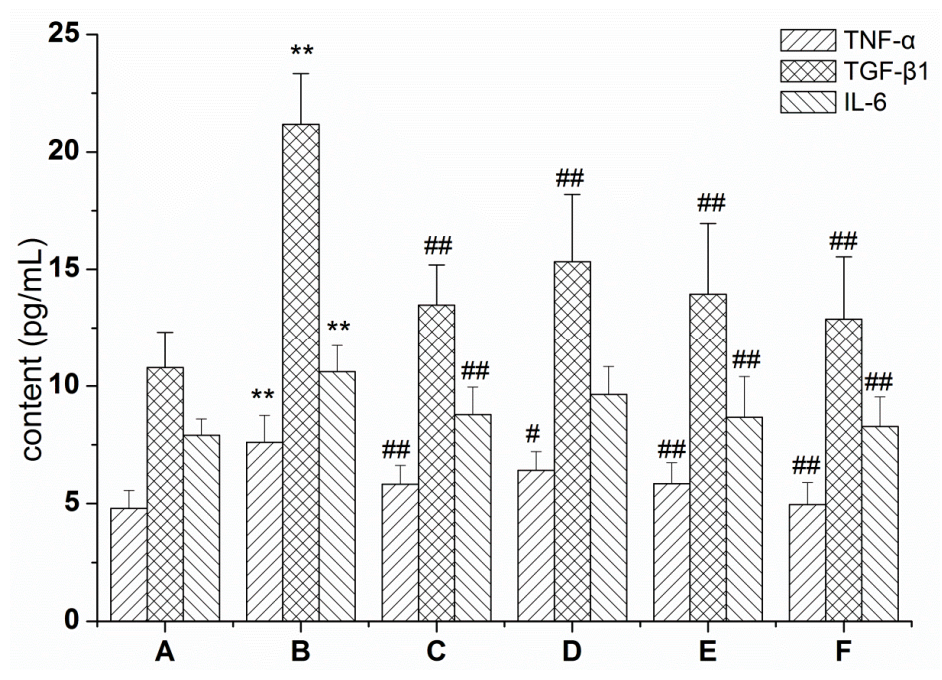

Figure 1. Effects of RRL (Rhodiola rosea $\mathrm{L}$.) on the levels of transforming growth TNF- $\alpha$ (tumor necrosis factor- $\alpha$ ), TGF- $\beta 1$ (transforming growth factor- $\beta 1$ ) and IL-6 (interleukin 6) in the BALF (bronchoalveolar lavage fluid) of BLM (bleomycin)-treated rats. ( ${ }^{* *} p<0.01$ vs. the normal control group; ${ }^{*} p<0.05$ vs. the BLM-treated group; ${ }^{\# \#} p<0.01$ vs. the BLM group). (A) normal group; (B) model group; (C) PAG (prednisone acetate) group; (D-F) are RRL group treated with 125, 250 and $500 \mathrm{mg} / \mathrm{kg}$.
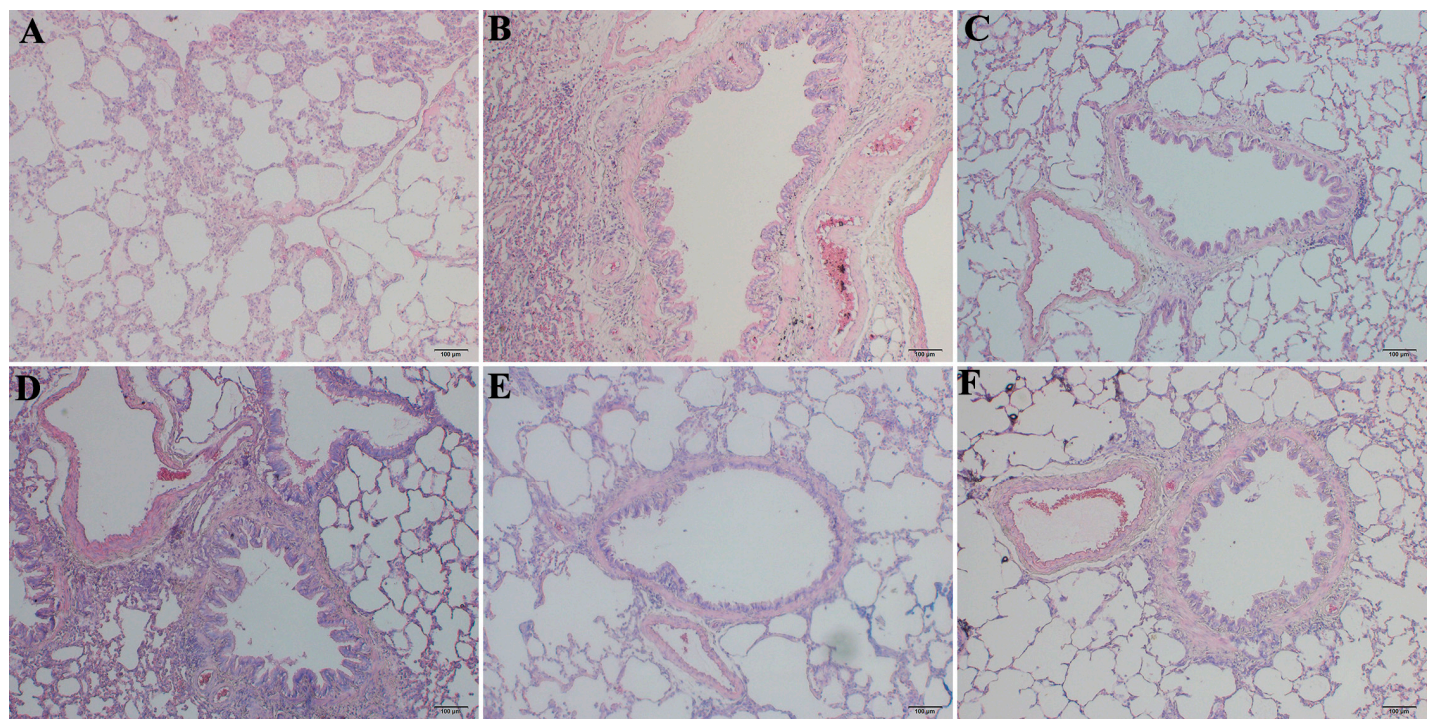

Figure 2. The $\mathrm{H} \& \mathrm{E}$ of the lung tissues in rats $(\mathrm{Bar}=100 \mu \mathrm{m})$. (A) normal group; $(\mathbf{B})$ model group; (C) PAG group; (D-F) are RRL groups treated with 125, 250 and $500 \mathrm{mg} / \mathrm{kg}$, respectively.

Masson's trichrome staining of lung specimens demonstrated that BLM severely distorted lung structure and collagen fibers (blue) accumulated in the rat lungs. Figure 3B depicts the marked deposition of deep blue-stained mature collagen fibers surrounding the pulmonary vessels in the model group. Collagen deposition in the RRL group was significantly reduced compared with that in the model group. These results show that RRL alleviated collagen deposition and inflammation induced by BLM. 


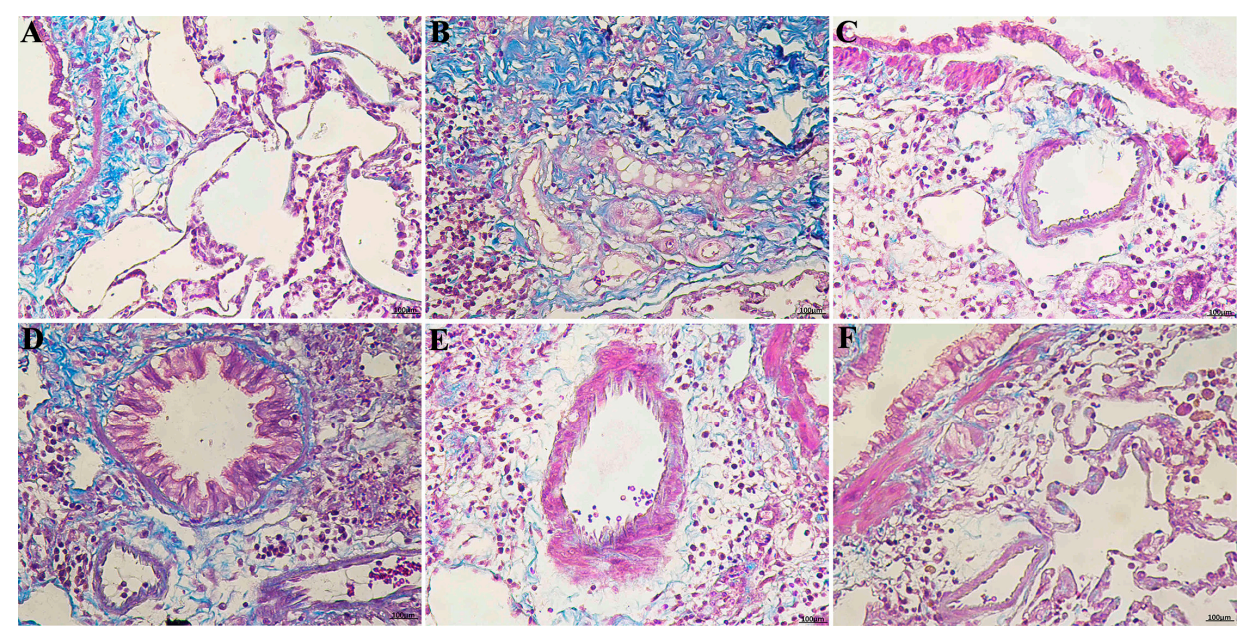

Figure 3. The Masson examinations of the lung tissues in rats (Bar $=100 \mu \mathrm{m})$. (A) normal group; (B) model group; (C) PAG group; (D-F) are RRL groups treated with 125, 250 and $500 \mathrm{mg} / \mathrm{kg}$, respectively.

\subsection{RRL Reduces the BLM-Induced Loss of Body Weight in Rats}

As shown in Table 1, the body weights of the rats decreased significantly seven days after the BLM treatment commenced and decreased gradually thereafter $(n=10, p<0.01)$. However, body weight increased significantly on days 14,21 , and 28 after initiating the RRL treatment $(p<0.05$ and $p<0.01$ vs. model group). These results suggest that RRL increased the body weight of rats with PF.

Table 1. Changes of body weight after drugs intervention $(n=10)$.

\begin{tabular}{cccccc}
\hline Group & Day 1 & Day 7 & Day 14 & Day 21 & Day 28 \\
\hline A & $185.3 \pm 2.2$ & $209.9 \pm 8.5$ & $243.3 \pm 13.4$ & $262.5 \pm 19.6$ & $294.0 \pm 16.6$ \\
$\mathrm{~B}$ & $190.7 \pm 5.4$ & $190.4 \pm 22.2^{*}$ & $195.0 \pm 18.9^{* *}$ & $227.7 \pm 21.4^{* *}$ & $236.0 \pm 18.5^{* *}$ \\
$\mathrm{C}$ & $186.9 \pm 6.5$ & $181.1 \pm 15.1$ & $183.8 \pm 19.2$ & $255.4 \pm 21.9^{\# \#}$ & $270.3 \pm 20.3^{\# \#}$ \\
$\mathrm{D}$ & $187.3 \pm 4.8$ & $192.6 \pm 18.0$ & $219.1 \pm 9.6^{\# \#}$ & $253.0 \pm 14.3^{\#}$ & $279.3 \pm 14.8^{\# \#}$ \\
$\mathrm{E}$ & $190.9 \pm 3.1$ & $196.2 \pm 12.0$ & $225.5 \pm 12.8^{\# \#}$ & $273.4 \pm 20.8^{\# \#}$ & $282.0 \pm 18.4^{\# \#}$ \\
$\mathrm{~F}$ & $189.6 \pm 6.9$ & $197.6 \pm 8.9$ & $223.3 \pm 8.8^{\# \#}$ & $272.9 \pm 23.7^{\# \#}$ & $284.6 \pm 9.3^{\# \#}$ \\
\hline Value are expressed with mean $\pm \mathrm{SD}(n=10) .^{*} p<0.05,{ }^{* *} p<0.01$ vs. the control group; ${ }^{*} p<0.05,{ }^{\# \#} p<0.01$ \\
vs. the model group. A: Normal group; B: Model group; C: PAG group; D-F are RRL group treated with 125, \\
250 and 500 mg/kg, respectively.
\end{tabular}

\subsection{RRL Attenuates HYP Expression and Increases GSH and T-SOD Activities in BLM-Treated Rats}

HYP is the main component in extracellular collagen and a hallmark of PF [19]. HYP content in the lungs of rats was determined to determine the effect of RRL on lung collagen content. HYP content increased significantly in BLM-treated rats compared to that in the normal group of rats after 28 days, whereas HYP content in the RRL group was significantly lower than that in the model group (Figure 4I). These results indicate that RRL lowered lung collagen content.

Oxidative stress contributes to various pathological conditions and diseases, and BLM promotes oxidative stress damage. BLM-induced oxidative injury was determined by measuring antioxidants, such as T-SOD and GSH, in rat serum. As a result, T-SOD and GSH decreased in serum and BLM-treated lung tissues, whereas they increased after RRL administration.

As shown in Figure 4II,III, serum GSH and T-SOD levels decreased significantly in the model group (T-SOD: $240.24 \pm 24.25 \mathrm{U} / \mathrm{mL}$ protein in the normal group vs. $171.84 \pm 25.73 \mathrm{U} / \mathrm{mL}$ protein in the model group; GSH: $11.92 \pm 3.39$ vs. $8.53 \pm 1.44 \mu \mathrm{mol} / \mathrm{L}$ protein). GSH and T-SOD activities in the RRL group were significantly higher than those in the model group. GSH concentration increased after the RRL $(125,250$, and $500 \mathrm{mg} / \mathrm{kg})$ treatments. Oral administration of $250 \mathrm{or} 500 \mathrm{mg} / \mathrm{kg}$ RRL 
significantly enhanced T-SOD levels compared with those in the model group $(p<0.01, p<0.05)$. These results show that RRL has antioxidative properties in BLM-induced lung lesions.
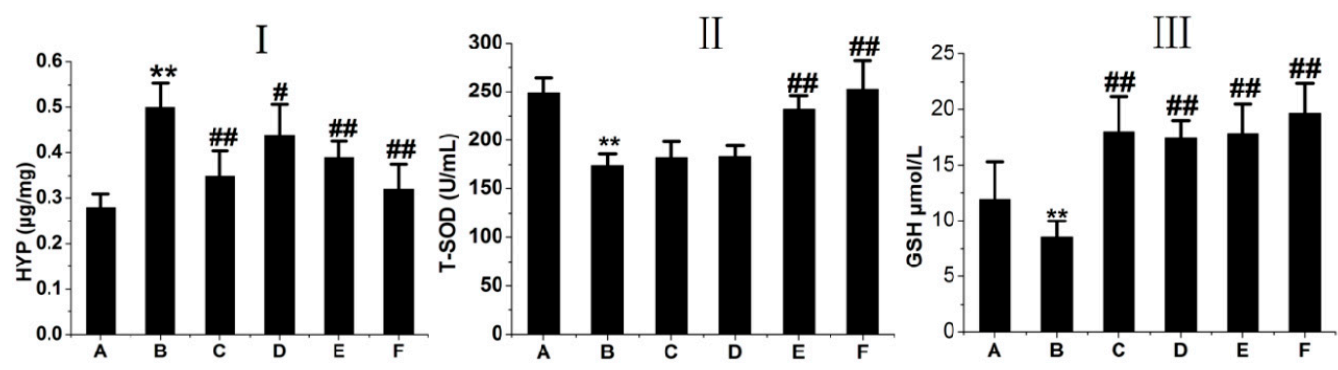

Figure 4. (I) lung tissue HYP (hydroxyproline) level in rats; (II) serum T-SOD (Total superoxide dismutase) level in rats; (III) serum GSH (glutathione hormone) level in rats. (A) normal group; (B) model group; (C) PAG group; (D-F) are RRL groups treated with 125, 250 and $500 \mathrm{mg} / \mathrm{kg}$, respectively. Compared with the Model group. ${ }^{* *} p<0.01$. Compared with control group, ${ }^{\#} p<0.05$; \#\# $p<0.01$.

\subsection{RRL Attenuates BLM-Induced $\alpha$-SMA, MMP-9, and TIMP-1 Expression in Rats}

$\alpha$-SMA, MMP-9, and TIMP-1 were immunolocalized as brown DAB precipitates in cells from lung fibrotic regions after 28 days. We observed significant inhibition of $\alpha$-SMA, MMP-9, and TIMP-1 expression in the RRL-treated rats compared to that in BLM-treated animals after 28 days. MMP-9, TIMP-1, and $\alpha$-SMA staining density was significantly lower in the RRL-treated rats than that in the model group.

As shown in Figures 5-7, BLM induced marked increases in $\alpha$-SMA, MMP-9, and TIMP-1 expression. In contrast, RRL significantly repressed over-expression of $\alpha$-SMA, MMP-9, and TIMP-1. Consistent with the immunohistochemical staining results, Western blot also revealed that $\alpha$-SMA and MMP-9 expression in the lungs of rats treated with RRL decreased significantly in a dose-dependent manner. Immunohistochemical staining of lung sections showed that RRL significantly decreased secretion of TIMP-1 in rats with BLM-induced PF $(p<0.05, p<0.01, p<0.001$ vs. model group; Figure $7 \mathrm{a}, \mathrm{b}$ and Figure 8 ), but no significant differences were detected by Western blot. Taken together, these results clearly show that RRL reduced $\alpha$-SMA and MMP-9 expression in the lungs of rats. Therefore, we conclude that the RRL extract probably mitigated $\alpha$-SMA and MMP-9 expression in rats with BLM-induced PF.

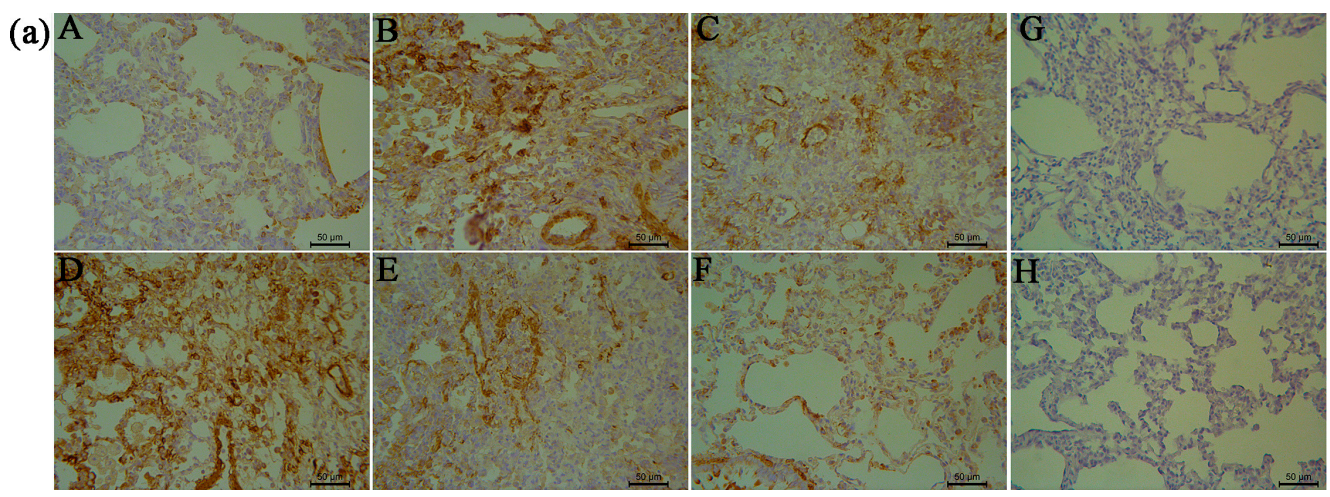

Figure 5. Cont. 


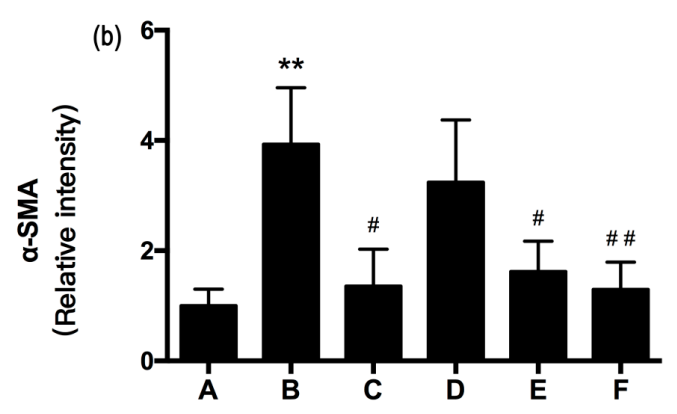

Figure 5. Effects of RRL on the levels of $\alpha$-smooth muscle actin ( $\alpha$-SMA) in the lung tissues after bleomycin (BLM)-induced in rats. (a) representative immunohistochemistry image (Bar $=50 \mu \mathrm{m})$. (A) normal group; (B) model group; (C) PAG group; (D-F) are RRL groups treated with 125, 250 and $500 \mathrm{mg} / \mathrm{kg}$, respectively; (G) negative control of omitted first antibody; $(\mathbf{H})$ negative control of omitted second antibody; (b) the quantitative analysis of $\alpha$-SMA protein in lung tissues. Data represent the mean \pm standard deviation (SD) $(n=3){ }^{* *} p<0.01$ vs. normal group, ${ }^{\#} p<0.05,{ }^{\#} p<0.01$, vs. model group).

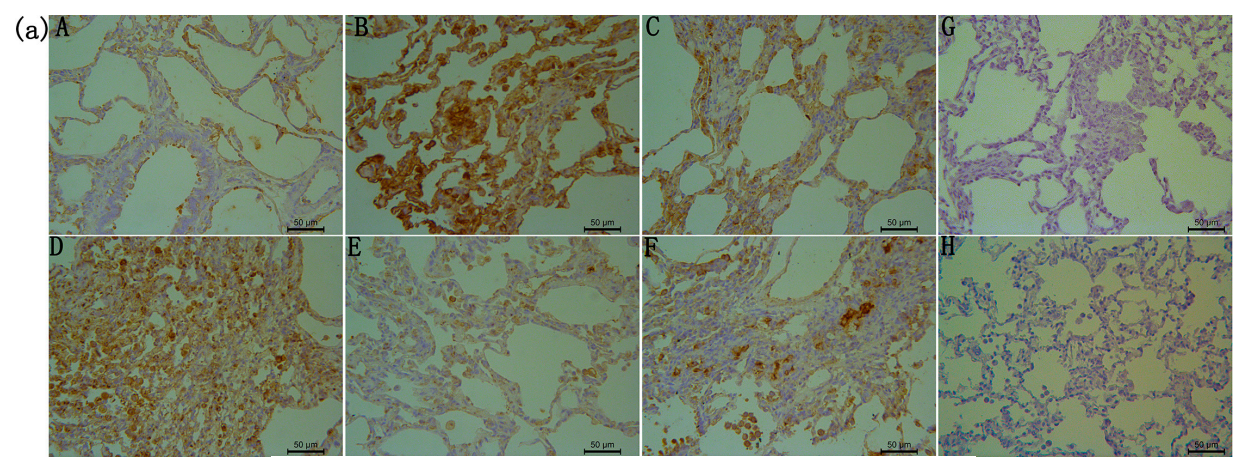

(b) 8

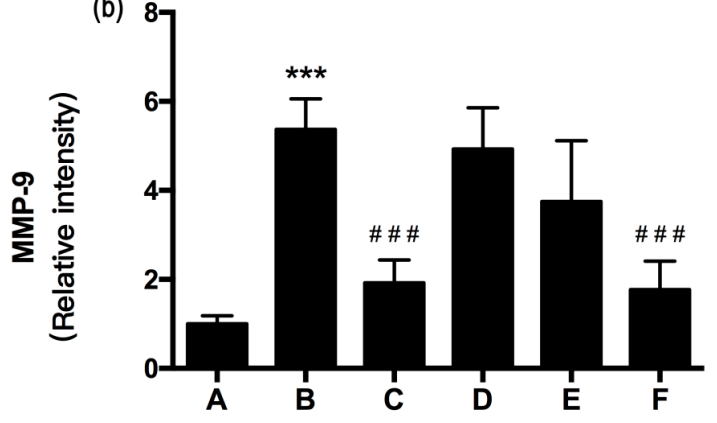

Figure 6. Effects of RRL on the levels of matrix metalloproteinase-9 (MMP-9) in the lung tissues after bleomycin (BLM)-induced in rats. (a) representative immunohistochemistry image (Bar $=50 \mu \mathrm{m})$. (A) normal group; (B) model group; (C) PAG group; (D-F) are RRL groups treated with 125, 250 and $500 \mathrm{mg} / \mathrm{kg}$, respectively; (G) negative control of omitted first antibody; (H) negative control of omitted second antibody; (b) the quantitative analysis of MMP-9 protein in lung tissues. Data represent the mean \pm standard deviation (SD) $(n=3)\left({ }^{* * *} p<0.001\right.$ vs. normal group, ${ }^{\# \# \#} p<0.001$ vs. model group).

We carried out immunohistochemical staining for $\alpha$-SMA to investigate proliferation and migration of smooth muscle cells, which contribute to PF pathogenesis. The negative-control (no primary antibody) histological sections did not show any brown staining (Figure 5G). $\alpha$-SMA is a marker of myofibroblast activation from quiescent lung interstitial fibroblasts. As shown in Figure 5b, BLM induced a marked increase in $\alpha$-SMA expression $(p<0.01)$, whereas $\alpha$-SMA expression in rats treated with RRL was significantly lower than that in the model group and decreased dose-dependently after RRL administration. 

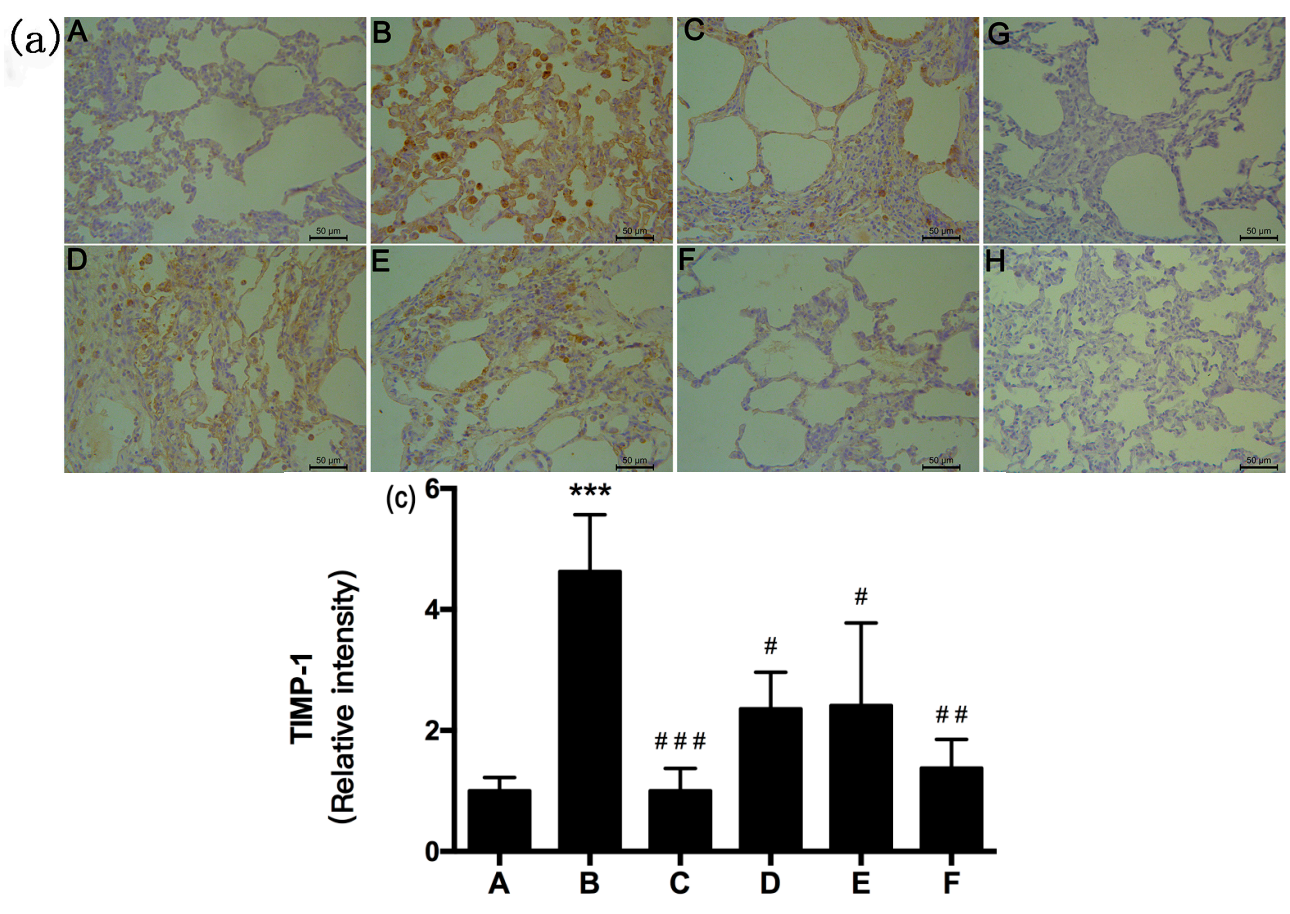

Figure 7. Effects of RRL on the levels of tissue inhibitors of metalloproteinase-1 (TIMP-1) in the lung tissues after bleomycin (BLM)-induced in rats. (a) representative immunohistochemistry image (Bar $=50 \mu \mathrm{m}$ ). (A) normal group; (B) model group; (C) PAG group; (D-F) are RRL groups treated with 125, 250 and $500 \mathrm{mg} / \mathrm{kg}$, respectively; (G) negative control of omitted first antibody; (H) negative control of omitted second antibody; (b) the quantitative analysis of TIMP-1 protein in lung tissues. Data represent the mean \pm standard deviation (SD) $(n=3)\left({ }^{* * *} p<0.001\right.$ vs. normal group, ${ }^{\#} p<0.05$, \#\# $p<0.01,{ }^{\# \#} p<0.001$ vs. model group).

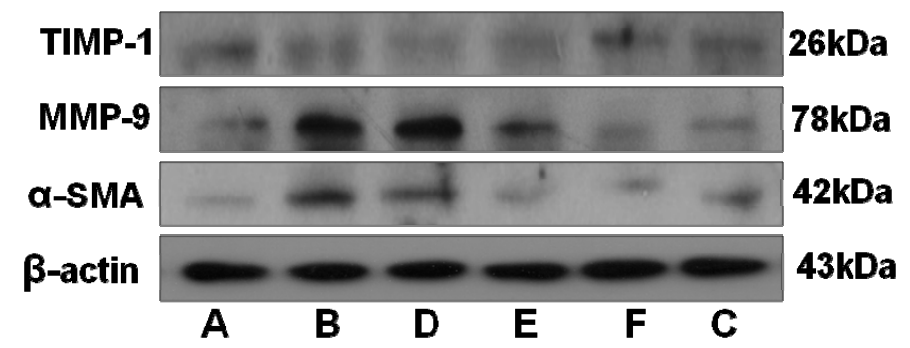

Figure 8. Expression level of TIMP-1, MMP-9 and $\alpha$-SMA of the lung tissues in rats. (A) normal group; (B) model group; (C) PAG group; (D-F) are RRL groups treated with 125, 250 and $500 \mathrm{mg} / \mathrm{kg}$, respectively.

$\mathrm{PF}$ is a cryptic, chronic disease, resulting in progressive and severe pulmonary insufficiency, but the pathogenesis remains poorly understood. The main features of PF include fibroblast proliferation and accumulation of ECM components. The molecular mechanisms responsible for the aberrant tissue remodeling likely involve MMPs and TIMPs, which are the main mediators of ECM turnover.

The negative control (no primary antibody) histological sections for MMP-9 and TIMP-1 immunohistochemistry showed no brown staining (Figures 6G and 7G). Weak MMP-9 and TIMP-1 expression was observed in the organs surrounding the lungs in rats in the normal group. The model group showed significantly increased expression of MMP-9 and TIMP-1 ( $p<0.001$ vs. normal group), compared to that in the normal group. Rats in the model group had a broad distribution of MMP-9 and TIMP-1 in bronchial subepithelial tissue and pulmonary interstitial and perivascular spaces. MMP-9 and TIMP-1 expression levels in the RRL group were lower than those in the model group 
and decreased dose-dependently after RRL administration (Figures 6 and 7). Consistent with the immunohistochemical staining results, Western blot also revealed a suppressive effect of RRL on MMP-9 expression (Figure 8). Taken together, we inferred that RRL reduced $\alpha$-SMA and MMP-9 expression levels, which slightly ameliorated BLM-induced PF.

\subsection{RRL Attenuated BLM-Induced TGF- $\beta 1$ Expression in Rats}

TGF- $\beta 1$ is the major pro-fibrotic growth factor in lung fibrosis and one of the most widely studied pro-fibrotic cytokines [20-22]. TGF- $\beta 1$ is overexpressed in the lungs of mice during the development of severe interstitial and pleural fibrosis, consisting of excess collagen deposition and the presence of myofibroblasts. Our results show that TGF- $\beta 1$ was immunolocalized as a brown DAB precipitate in cells from lung fibrotic regions after 28 days. The negative control (no primary antibody) had no brown staining (Figure 9G). TGF- $\beta 1$ expression increased significantly in the model group $(p<0.001$; Figure 9a,b), whereas it decreased significantly in RRL-treated rats compared to that in BLM-treated animals after 28 days. TGF- $\beta 1$ staining intensity in RRL-treated rats was significantly lower than that observed in the model group $(p<0.05 ; p<0.001)$. These results show that RRL blocked BLM-induced TGF- $\beta 1$ signaling transduction in lung tissues.
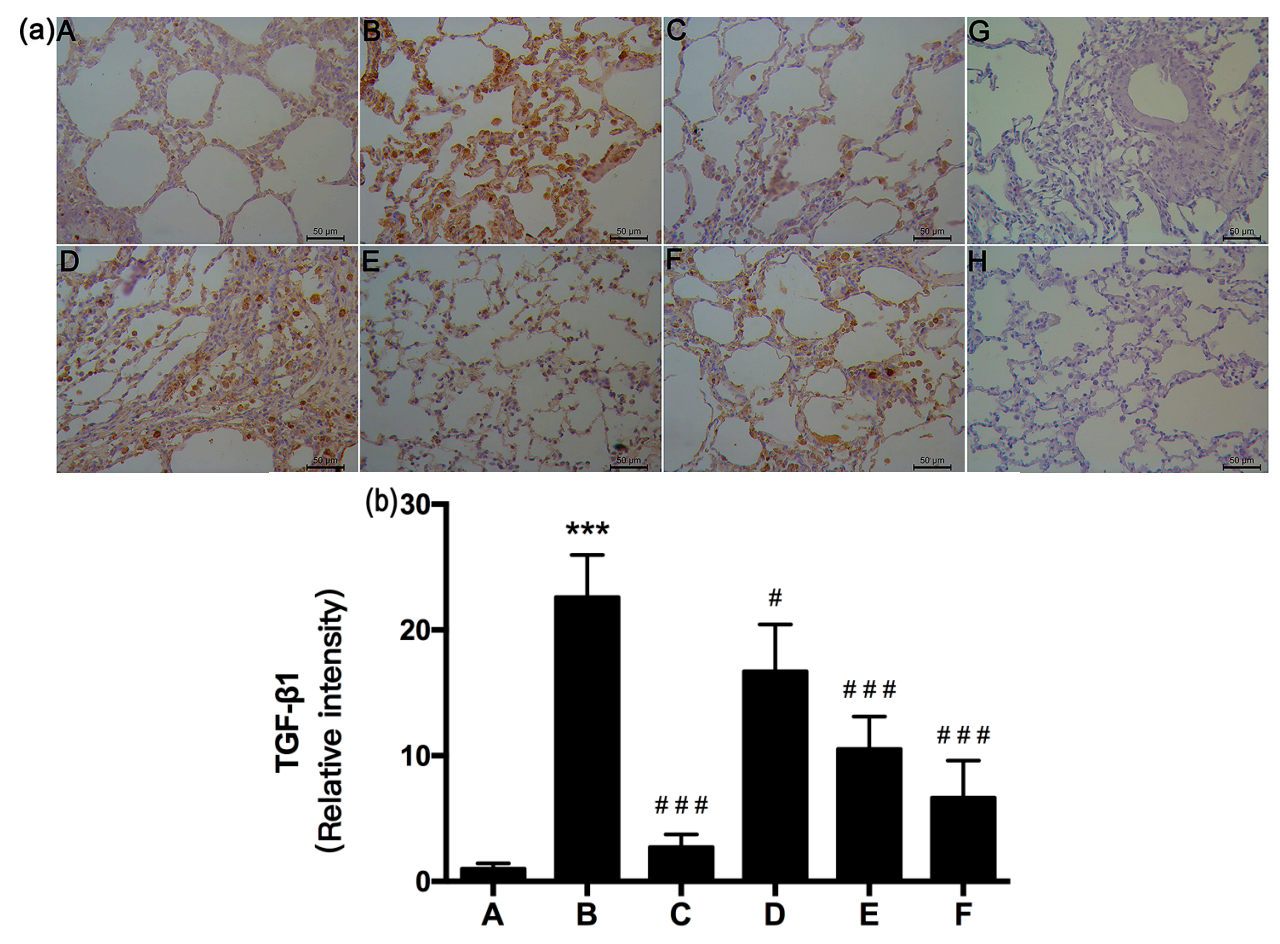

Figure 9. Effects of RRL on the levels of TGF- $\beta 1$ in the lung tissues after bleomycin (BLM)-induced in rats. (a) representative immunohistochemistry image (Bar $=50 \mu \mathrm{m})$. (A) normal group; (B) model group; (C) PAG group; (D-F) are RRL groups treated with 125, 250 and $500 \mathrm{mg} / \mathrm{kg}$, respectively; (G) negative control of omitted first antibody; $(\mathbf{H})$ negative control of omitted second antibody. Note the absence of the brown coloration; (b) the quantitative analysis of TGF- $\beta 1$ protein in lung tissues. Data represent the mean \pm standard deviation (SD) $(n=3)\left({ }^{* * *} p<0.001\right.$ vs. normal group, ${ }^{\#} p<0.05$, \#\#\# $p<0.001$ vs. model group).

\subsection{Small Molecule Compounds}

We identified the structures of nine small molecule compounds in RRL, and nine components were identified in the RRL by NMR, UV, and IR (Table 2). 
Table 2. The structures of compounds in Rhodiola rosea L.

\begin{tabular}{|c|c|c|c|}
\hline No. & Name & Structure & Identification Methods \\
\hline 1 & $\begin{array}{l}\text { 3,4,5-trihydroxybenzoic acid } \\
\text { (2S-cis)-3,4-dihydro-5,7-dihydroxy-2-(3,4,5-trihydroxyphenyl)-2H-benzo[b]pyran-3-yl ester }\end{array}$ & & $\begin{array}{c}{ }^{1} \mathrm{H}-\mathrm{NMR},{ }^{13} \mathrm{C}-\mathrm{NMR}, \mathrm{HMBC}, \\
\text { HSQC, CD, IR, UV, } \\
\text { HR-ESI-TOF-MS }\end{array}$ \\
\hline 2 & herbacetin-3-O- $\beta$-D-glucopyranoside-7-O- $\alpha$-L-rhamnoside & & $\begin{array}{c}{ }^{1} \mathrm{H}-\mathrm{NMR},{ }^{13} \mathrm{C}-\mathrm{NMR}, \mathrm{HMBC}, \\
\text { HR-ESI-TOF-MS }\end{array}$ \\
\hline 3 & kaempferol-7-O- $\alpha$-L-rhamnoside & & $\begin{array}{l}{ }^{1} \mathrm{H}-\mathrm{NMR},{ }^{13} \mathrm{C}-\mathrm{NMR}, \\
\text { HR-ESI-TOF-MS, m.p. }\end{array}$ \\
\hline 4 & Rhodiocyanoside A & & $\begin{array}{c}{ }^{1} \text { H-NMR, }{ }^{13} \text { C-NMR, } \\
\text { HR-ESI-TOF-MS }\end{array}$ \\
\hline 5 & Rosarin & & $\begin{array}{l}{ }^{1} \mathrm{H}-\mathrm{NMR},{ }^{13} \mathrm{C}-\mathrm{NMR}, \\
\text { HR-ESI-TOF-MS }\end{array}$ \\
\hline
\end{tabular}


Table 2. Cont

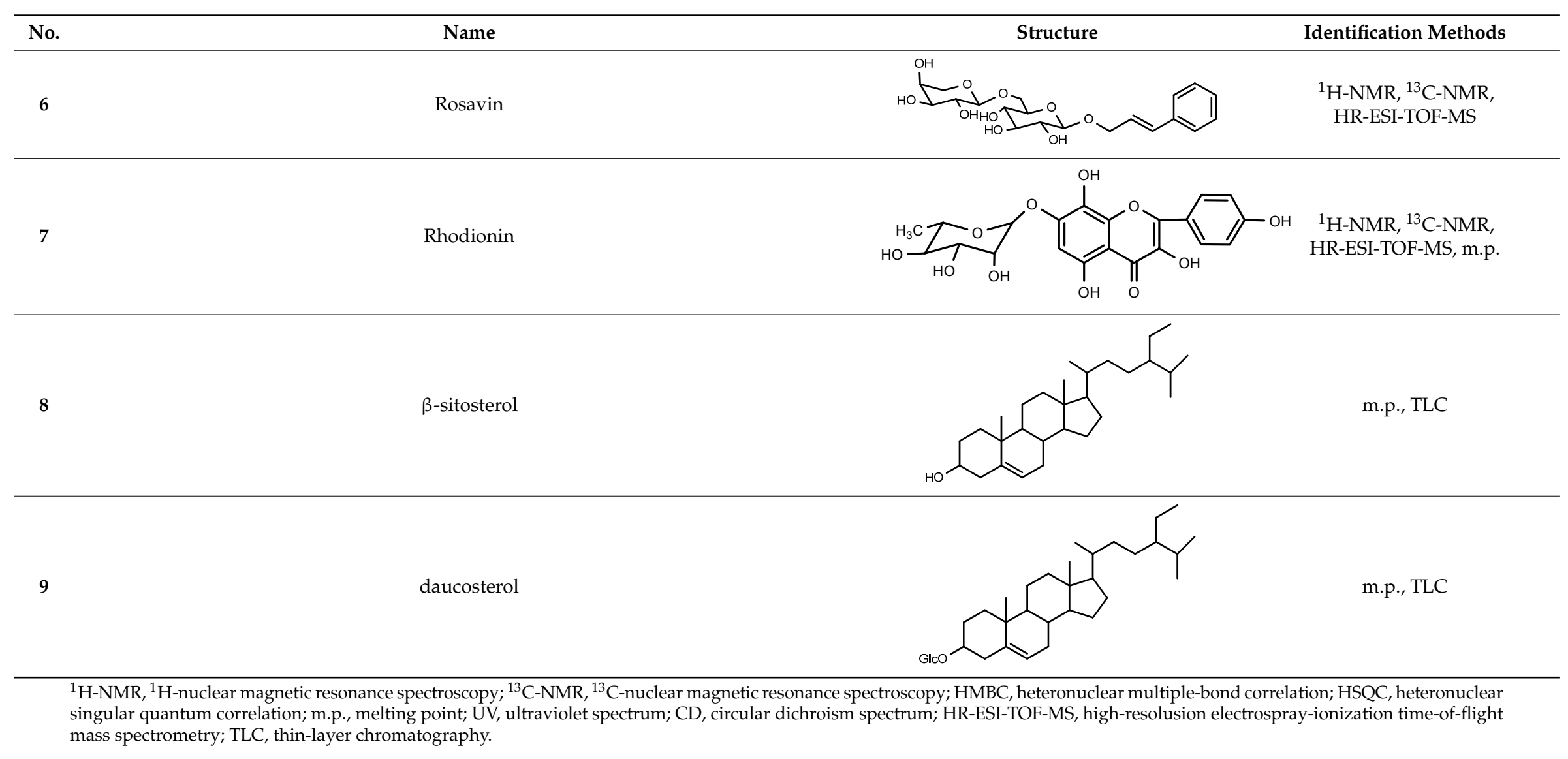


HMBC, heteronuclear multiple-bond correlation; HSQC, heteronuclear singular quantum correlation; NOESY, nuclear overhauser effect spectroscopy; m.p., melting point; UV, ultraviolet spectrum; $C D$, circular dichroism spectrum; HR-ESI-TOF-MS, high-resolusion electrospray-ionization time-of-flight mass spectrometry; TLC, thin-layer chromatography.

\subsection{Characterization of the RRL Constitutents by UPLC-TOF-MS}

UPLC-TOF-MS was employed to analyze the RRL crude extracts. Nine components were identified by NMR, UV, and IR by comparing the exact masses and formulae from their MS data by UPLC-MS. Among them, seven compounds showed satisfactory binding with FAP $\alpha$, based on the bioinformatics analysis results described above, including 3,4,5-trihydroxybenzoic acid (2S-cis)-3,4-dihydro-5,7-dihydroxy-2-(3,4,5-trihydroxyphenyl)-2H-benzo[ $b$ ]pyran-3-yl ester (1), herbacetin-3-O- $\beta$-D-glucopyranoside-7-O- $\alpha$-L-rhamnoside (2), kaempferol-7-O- $\alpha$-L-rhamnoside (3), Rhodiocyanoside A (4), Rosarin (5), Rosavin (6), and Rhodionin (7) (Table 3).

Table 3. The retention time (Rt) and mass (MS) characteristics of the main detected peaks in extracts of Rhodiola rosea $\mathrm{L}$.

\begin{tabular}{|c|c|c|c|c|c|c|}
\hline $\begin{array}{c}\text { Compound } \\
\text { No. }\end{array}$ & Compound Name & $\begin{array}{c}\text { Molecular } \\
\text { Formula }\end{array}$ & $\begin{array}{c}\text { Molecular } \\
\text { Weight }\end{array}$ & $\begin{array}{c}\mathrm{Rt} \\
(\mathrm{min})\end{array}$ & $\begin{array}{l}{[\mathrm{M}+\mathrm{H}]^{+} /} \\
{[\mathrm{M}+\mathrm{Na}]^{+}}\end{array}$ & $\begin{array}{r}\text { Error } \\
(\mathrm{ppm})\end{array}$ \\
\hline 1 & $\begin{array}{c}\text { 3,4,5-trihydroxybenzoic acid } \\
\text { (2S-cis)-3,4-dihydro-5,7-dihydroxy-2- } \\
\text { (3,4,5-trihydroxyphenyl)-2H-benzo[b]pyran-3-yl ester }\end{array}$ & $\mathrm{C}_{22} \mathrm{H}_{18} \mathrm{O}_{11}$ & 458.0849 & 5.10 & 459.0927 & -0.7 \\
\hline 2 & herbacetin-3-O- $\beta$-D-glucopyranoside-7-O- $\alpha$-L-rhamnoside & $\mathrm{C}_{27} \mathrm{H}_{30} \mathrm{O}_{16}$ & 610.1534 & 21.56 & 611.1612 & 0.8 \\
\hline 3 & kaempferol-7-O- $\alpha$-L-rhamnoside & $\mathrm{C}_{21} \mathrm{H}_{20} \mathrm{O}_{10}$ & 432.1056 & 12.29 & 433.1135 & 0.7 \\
\hline 4 & Rhodiocyanoside A & $\mathrm{C}_{11} \mathrm{H}_{17} \mathrm{NO}_{6}$ & 450.2465 & 1.86 & 260.1138 & 1.2 \\
\hline 5 & Rosarin & $\mathrm{C}_{20} \mathrm{H}_{28} \mathrm{O}_{10}$ & 428.1682 & 9.76 & 451.1578 & -0.4 \\
\hline 6 & Rosavin & $\mathrm{C}_{20} \mathrm{H}_{28} \mathrm{O}_{10}$ & 428.1682 & 10.58 & 451.1581 & 0.2 \\
\hline 7 & Rhodionin & $\mathrm{C}_{21} \mathrm{H}_{20} \mathrm{O}_{11}$ & 449.1084 & 21.60 & 449.1084 & 0.9 \\
\hline
\end{tabular}

\subsection{Molecular Docking of FAP- $\alpha$}

To identify the targets related to the preventive effects of RRL on BLM-induced PF, the seven compounds from RRL were selected for molecular docking targeting FAP- $\alpha$ to determine their effect on PF in rats. The molecular docking results were ranked by a score indicating the degree of interaction with FAP- $\alpha$, hence indicating their effectiveness for treating PF (Figure 10). The list is as follows: 3,4,5-trihydroxybenzoic acid (2S-cis)-3,4-dihydro-5,7-dihydroxy-2-(3,4,5-trihydroxyphenyl) -2H-benzo[b]pyran-3-yl ester (Figure 10A); Herbacetin-3-O- $\beta$-D-glucopyranoside-7-O- $\alpha$-L-rhamnoside (Figure 10B); Kaempferol-7-O- $\alpha$-L-rhamnoside (Figure 10C); Rhodiocyanoside A (Figure 10D); Rosarin (Figure 10E); Rosavin (Figure 10F); and Rhodionin (Figure 10G). 


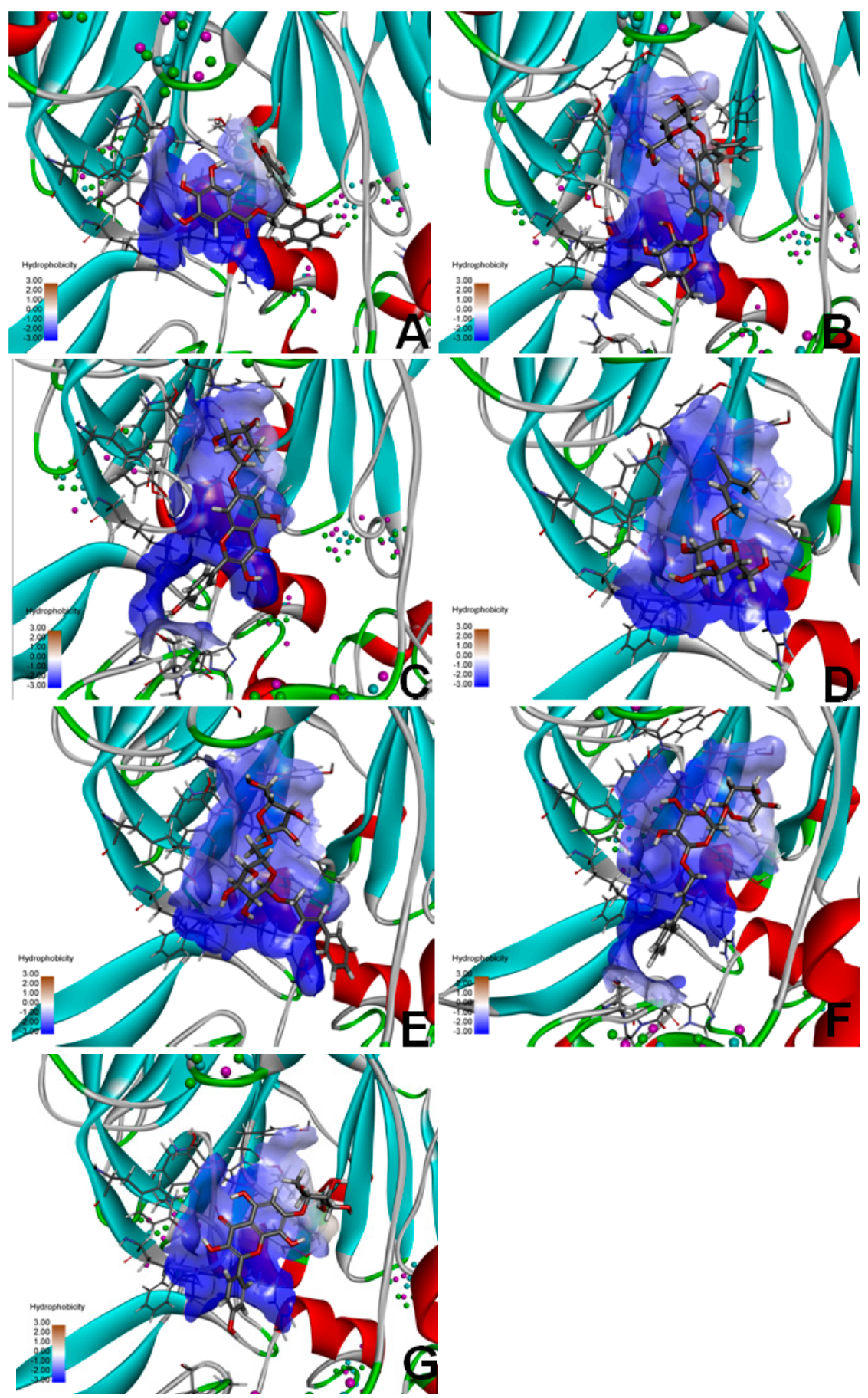

Figure 10. The docking results of the seven compounds interacting with the target protein fibroblast activation protein- $\alpha$ (FAP- $\alpha$ ). (A) 3,4,5-trihydroxybenzoic acid (2S-cis)-3,4-dihydro-5,7-dihydroxy -2-(3,4,5-trihydroxyphenyl)-2H-benzo[b]pyran-3-yl ester; (B) Herbacetin-3-O- $\beta$-D-glucopyranoside-7 -O- $\alpha$-L-rhamnoside; (C), Kaempferol-7-O- $\alpha$-L-rhamnoside; (D) Rhodiocyanoside A; (E) Rosarin; (F) Rosavin; (G) Rhodionin.

\section{Discussion}

The process of PF is complex, and the specific mechanism remains unclear. In this study, a rat model of PF was established by intratracheal injection of BLM [23]. BLM forms BLM-Fe ${ }^{2+}$ complexes, which provide electrons to oxygen molecules to form peroxides and hydroxyl radicals, leading to 
free radicals in deoxyribose of DNA. A large number of free radicals in lung tissue causes damage by lipid peroxidation and inflammation during early $\mathrm{PF}$, which further promotes proliferation of fibroblasts and alveolar-interstitial fibrosis [24]. The results of the present study show a significant increase in lung HYP content but decreased GSH content, T-SOD activity, and inflammatory factors in BAL, such as TNF- $\alpha$, TGF- $\beta 1$, and IL- 6 . In addition, the alveoli of the rats treated with BLM were structurally disordered, with obvious alveolitis, numerous alveolar septal fibroblasts, and ECM deposits typical of PF. The immunohistochemical results showed that $\alpha$-SMA, MMP-9, and TGF- $\beta 1$ expression increased in fibrotic lung tissue. These results suggest that the BLM-induced rat PF model was successfully established.

An important pathological feature of PF is excessive deposition of ECM, and HYP is a characteristic component of collagen. Therefore, we considered HYP as a PF indicator [25]. Our results show that HYP content in the lungs of BLM-treated rats was significantly higher than that in the normal group, whereas lung HYP content in the RRL-treated group was significantly lower than that in the BLM group, suggesting that the protective effects of RRL on BLM-induced PF were highly associated with decreased lung HYP content. We showed that RRL has powerful antioxidant capacity. Serum GSH and T-SOD activities increased significantly in the RRL-treated groups compared with those in the BLM group $(p<0.01)$, indicating clearance of reactive oxygens species, and enhanced antioxidant capacity, which reduced peroxidation of oxygen free radicals and damage to cells and tissues.

TGF- $\beta 1$ is a key fibrogenic cytokine that binds to receptors on fibroblasts and activates the TGF- $\beta$ /Smads signaling pathway. Tanjore et al. demonstrated that fibroblasts differentiate into an ECM-producing myofibroblast phenotype when tissues become fibrotic, which further exacerbates tissue stiffness and injury [26,27]. However, the metabolic disorder in the ECM during PF may cause excessive deposition of ECM, subsequently leading to PF. MMPs and TIMPs normally maintain dynamic equilibrium in the ECM. MMP-9 is involved in degrading and reconstructing the ECM, and enhanced MMP and decreased TIMP activities undermine homeostasis of the ECM. TGF- $\beta 1$ regulates MMP-9 and TIMP-1 expression and the metabolic imbalance in the ECM, which reduces ECM deposition in the stroma, to mitigate and contain the development of PF. Moreover, TGF- $\beta 1$ enhances phosphorylation of Smad 2 and Smad 3 in cells, leading to the TGF- $\beta$-dependent EMT and subsequent development and progress of fibrosis-related lung diseases [28,29]. We speculate based on previous studies, and our results, that RRL would inhibit phosphorylation of Smad3 caused by the decrease in TGF- $\beta 1$. However, the actual effect of RRL on p-Smad3 expression requires further study, which may more clearly elucidate the underlying mechanisms of the RRL-induced protective effect on PF.

In this study, the pathological observations in lung tissue showed that rats treated with the high dose of RRL had less lung inflammation and fibrosis than those in BLM-treated rats. We also determined that RRL significantly reduced $\alpha$-SMA and MMP-9 expression in the BLM-induced PF rat model. Consistently, this study showed that expression of MMP-9 increased significantly while TGF- $\beta 1$ was inhibited in the lungs of rats. These results strongly suggest that RRL attenuated BLM-induced fibrotic lung injury in rats.

\section{Materials and Methods}

\subsection{Reagents}

The roots and rhizomes of Rhodiola rosea L. (RRL) were collected in Tacheng Xinjiang of China in October 2007 and identified by Yong Tan (Shihezi University, China). A voucher specimen (No. 20071003001) was deposited in the School of Pharmacy, Shihezi University. Bleomycin (BLM) and prednisone acetate were purchased from Nippon Kayaku (Tokyo, Japan) and Tianjin Lisheng Pharmaceutical Co., Ltd. (Tianjin, China), respectively. Hydroxyproline (HYP; Nanjing Jiancheng Biological Engineering Research Institute, Nanjing, China), glutathione (GSH; Nanjing Jiancheng Biological Engineering Research Institute), and total superoxide dismutase (T-SOD; Nanjing Jiancheng 
Bioengineering Institute) were purchased commercially. Enzyme-linked immunosorbent assay (ELISA) kits for rat TNF- $\alpha$ (Shanghai Xitang, Shanghai, China), IL-6 (Shanghai Xitang), and TGF- $\beta 1$ (Shanghai Xitang) were used according to the manufacturer's instructions. Mouse anti- $\alpha$-SMA monoclonal antibody (Boster Biological Technology, Pleasanton, CA, USA), rabbit anti-MMP-9 polyclonal antibody, rabbit anti-TGF- $\beta 1$ polyclonal antibody (Boster Biological Technology) and horseradish peroxidase (HRP)-labeled goat anti-rabbit IgG antibody (Boster Biological Technology) were purchased and used as received. RIPA (Radio Immunoprecipitation Assay) lysis buffer (Solarbio Biological Technology, Beijing, China), BCA (Bicinchoninic acid) Protein Assay Kit (Solarbio Biological Technology), HRP-conjugated secondary antibodies (Boster Biological Technology), and an ECL (Enhanced Chemiluminescent) detection kit (Beyotime, Haimen, China) were also obtained.

\subsection{Preparation of RRL Extract}

The air-dried roots and rhizomes of RRL were refluxed three times with 95\% ethanol (1:10) $(2 \mathrm{~h} \times 3)$. The combined $95 \%$ ethanol extracts were concentrated in a vacuum at $45^{\circ} \mathrm{C}$ to generate a crude extract.

\subsection{Ultra High Pressure Liquid Chromatography Time-of-Flight Mass Spectrometry (UPLC-TOF-MS) Analysis}

The analytical procedure was performed using a system consisting of a Waters Acquity UPLC (Ultra Performance Liquid Chromatography) and Waters LCT Premier XE time-of-flight mass spectrometer (Waters Inc., Milford, MA, USA). Chromatography was performed using an ACQUITY UPLC ${ }^{\circledR}$ BEH C18 column $(2.1 \times 50 \mathrm{~mm}, 1.7 \mu \mathrm{m})$, and column temperature was maintained at $30^{\circ} \mathrm{C}$. The mobile phase (flow rate, $0.2 \mathrm{~mL} / \mathrm{min}$ ) consisted of solvent $\mathrm{A}$ ( $1 \%$ formic acid) and solvent $\mathrm{B}$ (50:50 menthol: acetonitrile with $1 \%$ formic acid), using the following gradient elution profile: $0-7 \mathrm{~min}$, 9\%-20\% A; 7-18 min, 20\%-22\% A; 18-25 min, 22\%-50\% A; and 25-27 min; and 50\%-95\% B. The mass spectrometer was optimized in $\pm \mathrm{V}$ mode, source temperature was set to $100{ }^{\circ} \mathrm{C}$ with cone gas flow of $30 \mathrm{~L} / \mathrm{h}$, desolvation gas temperature was $300{ }^{\circ} \mathrm{C}$, desolvation gas flow was $650 \mathrm{~L} / \mathrm{h}$, capillary voltage was $2200 \mathrm{~V}$, sample cone voltage was $100 \mathrm{~V}$, and extraction cone voltage was $100 \mathrm{~V}$. The data were processed using Masslynx 4.1 software (Waters Inc.).

\subsection{Animals}

Male Sprague-Dawley (SD) rats (weight, $200 \pm 20 \mathrm{~g}$ ) were obtained from the Animal Center of Urumqi (Certificate No. SCXK [xin] 2011-0003, Urumqi, China) and maintained on a 12-h light/dark cycle at a controlled temperature with free access to food and tap water. Animal welfare and the experimental procedures were in accordance with the Ethical Regulations on the Care and Use of Laboratory Animals of Shihezi University, and all animal experiments were performed with the approval and under the guidelines of the Animal Experimental Ethics Committee of the First Affiliated Hospital of medical college, Shihezi University (A2012-016, 30 May 2012).

\subsection{BLM-Induced PF Rat Model}

Forty-eight male SD rats were divided randomly into the following six groups: normal control, model (BLM group), prednisone acetate control (PAG group, $3.34 \mathrm{mg} / \mathrm{kg}$ ), and three groups received oral RRL $(125,250$, and $500 \mathrm{mg} / \mathrm{kg})$. BLM was used to induce PF. Briefly, the rats were anesthetized with an injection of $10 \%$ chloride hydrate $(3.5 \mathrm{~mL} / \mathrm{kg})$ and administered a single intratracheal instillation of saline containing $5 \mathrm{mg} / \mathrm{kg}$ BLM [30]. The rats were rotated immediately to ensure a thorough drug distribution in the lungs. Rats in the control group underwent the same surgical procedure but were given an equal volume of saline instead of BLM $(5 \mathrm{mg} / \mathrm{kg})$. Thereafter, the rats in the control and BLM groups were administered saline $(10 \mathrm{~mL} / \mathrm{kg}$ body weight $)$ intragastrically once daily. RRL (10 mL/kg body weight) was dissolved in saline and administered once by oral gavage. The positive control group was treated with the same volume of PAG in saline. The body weights of 
the rats were monitored weekly, and all rats were killed after 28 days. Blood samples were collected from the abdominal artery, centrifuged at $4000 \mathrm{rpm}$ for $10 \mathrm{~min}$ at $4{ }^{\circ} \mathrm{C}$ to obtain the serum, and stored at $-80^{\circ} \mathrm{C}$ before assay. Then, bronchoalveolar lavage fluid (BALF) was collected by intratracheal instillation and drainage of $5 \mathrm{~mL}$ phosphate buffered saline (PBS) three times. Half of the left lung tissue was removed and fixed in $4 \%$ paraformaldehyde, and the other half was frozen to prepare the homogenate.

\subsection{Lung Collagen Content}

Lung collagen content was evaluated using an HYP kit according to the manufacturer's protocol. Briefly, $50 \mathrm{mg}$ of frozen lung tissue sample was hydrolyzed in $1 \mathrm{~mL}$ lysis buffer at $95^{\circ} \mathrm{C}$ for $20 \mathrm{~min}$, and absorbance was measured at $550 \mathrm{~nm}$. Each sample was run in triplicate. Collagen content in pulmonary tissues was expressed as micrograms of hydroxyproline per gram wet lung weight $(\mu \mathrm{g} / \mathrm{g})[31,32]$.

\subsection{Antioxidant Enzyme Activities}

T-SOD and GSH activities were determined using kits according to the manufacturer's instructions. T-SOD data are expressed as U/mL. The GSH reaction was measured at $405 \mathrm{~nm}$, and enzyme activity is presented as $\mu \mathrm{mol} / \mathrm{L}$.

\subsection{BALF Biochemical Analysis}

The BALF was centrifuged at $1500 \mathrm{rpm}$ for $10 \mathrm{~min}$ at $4{ }^{\circ} \mathrm{C}$, and the supernatant was stored immediately at $-80^{\circ} \mathrm{C}$. BALF levels of TNF- $\alpha$, TGF- $\beta 1$, and IL- 6 were determined using commercially available ELISA kits according to the manufacturer's instructions. The optical density value was determined at $450 \mathrm{~nm}$ using an ELISA reader and calculated at the linear portion of the curve. The data are presented as picograms per milliliter $(\mathrm{pg} / \mathrm{mL})$ BALF.

\subsection{Histopathological Examination}

Lung specimens were fixed in $10 \%$ formalin and embedded in paraffin. The paraffin-embedded specimens were sectioned into $5-\mu \mathrm{m}$ thick slices, deparaffinized in xylene for $15 \mathrm{~min}$, hydrated in a graded alcohol series, and rinsed three times with $1 \%$ PBS. The slices were stained with hematoxylin and eosin ( $\mathrm{H} \& \mathrm{E})$ and Masson's trichrome for microscopic observations according to the manufacturer's standard protocols. Masson's trichrome stain was used to show collagen deposition, as collagen fibers stain blue. Nuclei stained dark red/purple, and the cytoplasm stained red/pink. The sections were examined under a Nikon 80i plus confocal laser-scanning microscope (Nikon, Tokyo, Japan) at $\times 100$ magnification.

\subsection{Immunohistochemical Staining}

MMP-9, TIMP-1, TGF- $\beta 1$, and $\alpha$-SMA expression levels in the lung were detected by immunohistochemistry. The sections $(5-\mu \mathrm{m})$ were dewaxed, rehydrated, washed in PBS, and endogenous peroxidase was inactivated with $3 \% \mathrm{H}_{2} \mathrm{O}_{2}$ for 15 min at room temperature. After washing three times with PBS, the sections were blocked with normal goat serum for $30 \mathrm{~min}$ at $37^{\circ} \mathrm{C}$ and incubated with primary antibodies against MMP-9 (1:200), TIMP-1 (1:100), TGF- $\beta 1$ (1:100), and $\alpha$-SMA (1:200) overnight at $4{ }^{\circ} \mathrm{C}$. After washing the slides three times with PBS, the sections were incubated with secondary peroxidase-conjugated affinity pure goat anti-rabbit IgG antibody $(\mathrm{H}+\mathrm{L})\left(1: 50\right.$; ZSGB-BIO, Beijing, China) for $20 \mathrm{~min}$ at $37^{\circ} \mathrm{C}$. The sections were washed with PBS and incubated for $15 \mathrm{~min}$ with the streptavidin-biotin-peroxidase complex. After washing with PBS, diaminobenzidine (DAB) was added as a visualizing agent. The nuclei were counterstained with hematoxylin. A negative control was created by omitting the primary or secondary antibody. The sections were examined under a Nikon 80i plus confocal laser-scanning microscope. Each sample 
was tested in triplicate. The number of positively stained cells in each tissue section was calculated from a $50 \mu \mathrm{m}$ magnified field under a light microscope. For immunohistochemical analyses of MMP-9, TIMP-1, TGF- $\beta 1$, and $\alpha$-SMA, staining density was determined using Image Pro plus 6.0 software (Media Cybernetics, Silver Spring, MD, USA) in one field of each section with a prominent DAB reaction.

\subsection{Western Blotting}

Tissues were collected from each treatment and suspended in RIPA lysis buffer. The lysed tissue was centrifuged at $12,000 \times g$ for $10 \mathrm{~min}$, the supernatant was collected, and protein content was determined using a BCA Protein Assay Kit. The proteins were separated by $12 \%$ sodium dodecyl sulfate-polyacrylamide gel electrophoresis and transferred to a PVDF (polyvinylidene fluoride) membrane (Millipore Corp., Billerica, MA, USA). The membranes were blocked with 5\% nonfat milk in TBST (Tris-Buffered Saline and Tween 20) and the target proteins were incubated overnight with primary antibodies against $\alpha$-SMA (1:500) and MMP-9 (1:500). After four 10-min washes with TBST, the membranes were incubated with HRP-conjugated secondary antibodies (1:1000) for $2 \mathrm{~h}$ at room temperature. The blots were washed four times in TBST buffer, subjected to an ECL detection kit, and exposed to photographic film. $\beta$-Actin served as the internal standard for protein loading and transfer.

\subsection{Isolation and Identification of the Main Components in Rhodiola rosea L.}

We isolated 10 compounds and identified their structures by applying silica gel (200-300 mesh; Qingdao Marine Chemical Group Co., Qingdao, China), Sephadex LH-20 (General Electric, Fairfield, CA, USA), ODS (30-50 $\mu \mathrm{m}$; YMC Co., Ltd., Tokyo, Japan), and UPLC-TOF-MS. In brief, the dried RRL roots and rhizomes $(2.0 \mathrm{~kg})$ were refluxed three times with EtOH: $\mathrm{H}_{2} \mathrm{O}(95: 5, v / v, 20 \mathrm{~L})$. The ethanol extract was harvested by vacuum concentration $(340 \mathrm{~g})$. The extract was suspended in water $(2.0 \mathrm{~L})$ and extracted stepwise with petroleum ether $(\mathrm{PE}), \mathrm{CHCl}_{3}, \mathrm{EtOAc}$, and $n-\mathrm{BuOH}(3 \times 2.0 \mathrm{~L})$ to obtain PE-soluble (8.0 g), $\mathrm{CHCl}_{3}$-soluble (16 g), EtOAc-soluble (56 g), and $n$-BuOH-soluble fractions (204 g). The EtOAc-soluble fraction (50 g) was subjected to silica gel column chromatography (CC) and eluted with $\mathrm{CHCl}_{3}$ containing an increasing volume of $\mathrm{MeOH}$ to afford 15 fractions (A-O: 100:0-0:100). Fraction $\mathrm{E}\left(\mathrm{CHCl}_{3}-\mathrm{MeOH}, 100: 4.5\right)$ (1.2 g) was applied to silica gel CC, eluted with $\mathrm{CHCl}_{3}: \mathrm{MeOH}(4: 1)$, and isolated with absolute $\mathrm{MeOH}$ by Sephadex $\mathrm{LH}-20 \mathrm{CC}$ to produce compound 3 (45 mg). Fraction F-1 ( $\left.\mathrm{CHCl}_{3}: \mathrm{MeOH}, 100: 6\right)$ (2.8 g) was applied to Sephadex LH-20 and eluted with MeOH: $\mathrm{H}_{2} \mathrm{O}(50: 50)$ to produce compound 7 (42 mg). Fraction F-2 $\left(\mathrm{CHCl}_{3}: \mathrm{MeOH}, 100: 6\right)(1.8 \mathrm{~g})$ was applied to silica gel $\mathrm{CC}$ and eluted with $\mathrm{CHCl}_{3}: \mathrm{MeOH}(100: 8)$ to produce compound 1 (52 $\left.\mathrm{mg}\right)$.

An aliquot of the $n$-BuOH-soluble fraction (180 g) was subjected to silica gel CC using a $\mathrm{CHCl}_{3}: \mathrm{MeOH}$ gradient to afford 16 fractions (A-P: 100:0-0:100). Fraction $\mathrm{B}\left(\mathrm{CHCl}_{3}: \mathrm{MeOH}, 100: 1\right)(1.8 \mathrm{~g})$ was separated via HPLC, using $\mathrm{MeOH}: \mathrm{H}_{2} \mathrm{O}(35: 65, v / v)$ as the mobile phase to produce compound 4 (300 mg). Fraction $\mathrm{F}\left(\mathrm{CHCl}_{3}: \mathrm{MeOH}, 100: 6\right)$ (3.2 g) was separated via HPLC with $\mathrm{MeOH}: \mathrm{H}_{2} \mathrm{O}(23: 77$, $v / v)$ as the mobile phase to produce compound $5(100 \mathrm{mg})$. Fraction G-1 $\left(\mathrm{CHCl}_{3}: \mathrm{MeOH}, 100: 8\right)(2 \mathrm{~g})$ was separated via HPLC with $\mathrm{MeOH}: \mathrm{H}_{2} \mathrm{O}(32: 68, v / v)$ as the mobile phase to produce compound 6 (480 mg). Fraction G-1 ( $\left.\mathrm{CHCl}_{3}: \mathrm{MeOH}, 100: 8\right)(3.3 \mathrm{~g})$ was separated via HPLC with $\mathrm{MeOH}: \mathrm{H}_{2} \mathrm{O}$ $(35: 65, v / v)$ as the mobile phase to produce compound $2(82 \mathrm{mg})$. The structures of compounds 1-7 were identified by comparing their spectroscopic data with those reported in the literature [33-37]. The relevant chromatograms and mass spectral data of the active compounds are as follows.

Compound 1: colorless needle (MeOH), m.p. $192.6-193.6^{\circ} \mathrm{C}$ ultraviolet (UV) $(\mathrm{MeOH}) \lambda_{\max }(\log \varepsilon) \mathrm{nm}$ : 210 (4.93), 276 (4.10). CD (MeOH, $c=0.00552 \mathrm{~g} / 100 \mathrm{~mL}) \lambda_{\max }(\theta) \mathrm{nm}\left(\mathrm{deg} \cdot \mathrm{cm}^{2} \cdot \mathrm{dmol}^{-1}\right): 214(-788)$, 242 (-18), 278 (-210). Infrared (IR) $(\mathrm{KBr}) \vee\left(\mathrm{cm}^{-1}\right): 3172,2875,1699,1619,1532,1457,1314,1227$, 1133, 1021, 823. ESI-TOF-MS: 459.0931 [M + H] ${ }^{+}$(Calcd. for $\mathrm{C}_{22} \mathrm{H}_{19} \mathrm{O}_{11}$ 459.0927, 0.9 ppm), 917.1791 $[2 \mathrm{M}+\mathrm{H}]^{+}$(Calcd. for $\left.\mathrm{C}_{44} \mathrm{H}_{37} \mathrm{O}_{22} 917.1776,1.6 \mathrm{ppm}\right), 1375.2662[3 \mathrm{M}+\mathrm{H}]^{+}$(Calcd. for $\mathrm{C}_{66} \mathrm{H}_{55} \mathrm{O}_{33}$ 
1375.2626, $2.6 \mathrm{ppm}) ;{ }^{1} \mathrm{H}$-nucelar magnetic resonance (NMR) $\left(\mathrm{CD}_{3} \mathrm{OD}, 600 \mathrm{MHz}\right) \delta: 4.96$ (br. s. H-2), 5.36 (br. s. H-3), 2.66 (d, $J=16.8 \mathrm{~Hz}, \mathrm{H}-4)$ and $2.93(\mathrm{dd}, J=16.8,4.8 \mathrm{~Hz}, \mathrm{H}-4), 5.83$ (d, $J=2.4 \mathrm{~Hz}, \mathrm{H}-5)$, $6.82\left(2 \mathrm{H}, \mathrm{s}, \mathrm{H}-2^{\prime}, 6^{\prime}\right), 8.07$ (br.s, OH), $8.74(3 \mathrm{H}$, br.s, OH), $9.07(2 \mathrm{H}$, br.s, $\mathrm{OH}), 9.20(2 \mathrm{H}$, br.s, OH), 9.31 (2H, br.s, OH); ${ }^{13} \mathrm{C}-\mathrm{NMR}\left(\mathrm{CD}_{3} \mathrm{OD}, 150 \mathrm{MHz}\right)$ 8: 76.4 (C-2), 70.0 (C-3), 25.7 (C-4), 156.5 (C-5, 9), 94.3 (C-6), 155.6 (C-7), $95.5(\mathrm{C}-8), 97.3(\mathrm{C}-10), 128.6\left(\mathrm{C}-1^{\prime}\right), 105.4\left(\mathrm{C}-2^{\prime}, 6^{\prime}\right), 145.4\left(\mathrm{C}-3^{\prime}, 5^{\prime}\right), 132.3\left(\mathrm{C}-4^{\prime}\right), 165.2$ $\left(\mathrm{C}-1^{\prime \prime}\right), 119.2\left(\mathrm{C}-2^{\prime \prime}\right), 108.6\left(\mathrm{C}-3^{\prime \prime}, 7^{\prime \prime}\right), 145.6\left(\mathrm{C}-4^{\prime \prime}, 6^{\prime \prime}\right), 138.5\left(\mathrm{C}-5^{\prime \prime}\right)$.

Compound 2: yellow powder (MeOH), HR-ESI-TOF-MS: 609.1471 [M - H] $]^{-}$(Calcd. for $\mathrm{C}_{27} \mathrm{H}_{29} \mathrm{O}_{16}$ 609.1456, $2.5 \mathrm{ppm}) ;{ }^{1} \mathrm{H}-\mathrm{NMR}\left(300 \mathrm{MHz}, \mathrm{DMSO}-d_{6}\right) \delta: 12.03(1 \mathrm{H}, \mathrm{s}, 5-\mathrm{OH}), 10.22\left(1 \mathrm{H}, \mathrm{s}, 4^{\prime}-\mathrm{OH}\right), 8.85$ $(1 \mathrm{H}, \mathrm{s}, 8-\mathrm{OH}), 8.14\left(2 \mathrm{H}, \mathrm{d}, J=8.7 \mathrm{~Hz}, \mathrm{H}-2^{\prime}, 6^{\prime}\right), 6.90\left(2 \mathrm{H}, \mathrm{d}, J=8.7 \mathrm{~Hz}, \mathrm{H}-3^{\prime}, 5^{\prime}\right), 6.61(1 \mathrm{H}, \mathrm{s}, \mathrm{H}-6), 5.46$ $\left(1 \mathrm{H}, \mathrm{d}, J=6.6 \mathrm{~Hz}\right.$, glc-1), $5.50\left(1 \mathrm{H}\right.$, br.s, rha-1), $1.11\left(3 \mathrm{H}, \mathrm{d}, J=6.0 \mathrm{~Hz}\right.$, rha-CH $\left.{ }_{3}\right), 4.70 \sim 5.50(4 \mathrm{H}$, br.s, glc-2, 3, 4, 6-OH), 3.18 4.52 (6H, m, glc-2, 3, 4, 5, 6), $84.70 \sim 5.50$ (3H, br.s, rha-2, 3, 4-OH), 3.18 3.96 (4H, $\mathrm{m}$, rha-2, 3, 4, 5); ${ }^{13} \mathrm{C}-\mathrm{NMR}\left(75 \mathrm{MHz}, \mathrm{DMSO}-d_{6}\right) \delta$ : 157.1 (C-2), 133.3 (C-3), 177.5 (C-4), 152.2 (C-5), 99.4 (C-6), 150.8 (C-7), 144.9 (C-8), 127.2 (C-9), 105.6 (C-10), 121.1 (C-1'), 131.2 (C-2' , 6'), 160.2 (C-4'), 115.1 $\left(\mathrm{C}-3^{\prime}, 5^{\prime}\right), 101.5$ (glc-1), 74.3 (glc-2), 76.5 (glc-3), 70.8 (glc-4), 77.6 (glc-5), 61.0 (glc-6), 98.9 (rha-1), 70.6 (rha-2), 70.0 (rha-3), 71.8 (rha-4), 70.0 (rha-5), 18.0 (rha-6).

Compound 3: yellow powder (MeOH), m.p. $231.3-233.8{ }^{\circ} \mathrm{C}$, HR-ESI-TOF-MS: $433.1137[\mathrm{M}+\mathrm{H}]^{+}$ (Calcd. for $\left.\mathrm{C}_{21} \mathrm{H}_{21} \mathrm{O}_{10} 433.11350 .5 \mathrm{ppm}\right) ;{ }^{1} \mathrm{H}-\mathrm{NMR}\left(600 \mathrm{MHz}, \mathrm{CD}_{3} \mathrm{OD}\right) \delta: 8.10\left(2 \mathrm{H}, \mathrm{d}, J=8.4 \mathrm{~Hz}, \mathrm{H}-2^{\prime}\right.$, $\left.6^{\prime}\right), 7.33\left(2 \mathrm{H}, \mathrm{d}, J=8.4 \mathrm{~Hz}, \mathrm{H}-3^{\prime}, 5^{\prime}\right), 6.74(1 \mathrm{H}, \mathrm{d}, J=2.4 \mathrm{~Hz}, \mathrm{H}-8), 6.42(1 \mathrm{H}, \mathrm{d}, J=1.8 \mathrm{~Hz}, \mathrm{H}-6), 5.56(1 \mathrm{H}$, br.s, $J=2.4 \mathrm{~Hz}$, rha-1), $3.84(1 \mathrm{H}, \mathrm{dd}, J=3.6,3.0 \mathrm{~Hz}$, rha-2), $4.02(1 \mathrm{H}, \mathrm{m}$, rha-3), $3.48(1 \mathrm{H}, \mathrm{t}, J=9.6,9.0 \mathrm{~Hz}$, rha-4), $3.61\left(1 \mathrm{H}, \mathrm{m}\right.$, rha-5), $1.26\left(3 \mathrm{H}, \mathrm{d}, J=6.0 \mathrm{~Hz}\right.$, rha-6); ${ }^{13} \mathrm{C}-\mathrm{NMR}\left(150 \mathrm{MHz}, \mathrm{CD}_{3} \mathrm{OD}\right) 8: 148.7(\mathrm{C}-2)$, 137.5 (C-3), 177.5 (C-4), 163.3 (C-5), 99.8 (C-6), 162.3 (C-7), 95.3 (C-8), 157.7 (C-9), 106.2 (C-10), 122.1 $\left(\mathrm{C}-1^{\prime}\right), 130.8\left(\mathrm{C}-2^{\prime}, 6^{\prime}\right), 160.8\left(\mathrm{C}-4^{\prime}\right), 116.4\left(\mathrm{C}-3^{\prime}, 5^{\prime}\right), 99.9$ (rha-1), 71.7 (rha-2), 73.6 (rha-3), 71.2 (rha-4), 72.1 (rha-5), 18.1 (rha-6).

Compound 4: colorless glassy substance (MeOH), HR-ESI-TOF-MS: $282.0951[\mathrm{M}+\mathrm{Na}]^{+}$(Calcd. for $\left.\mathrm{C}_{11} \mathrm{H}_{17} \mathrm{NO}_{6} \mathrm{Na} 282.0954,-1.1 \mathrm{ppm}\right) ;{ }^{1} \mathrm{H}-\mathrm{NMR}\left(600 \mathrm{MHz}\right.$, DMSO- $\left.d_{6}\right) \delta: 6.50(1 \mathrm{H}, \mathrm{td}, J=1.8,6.6,7.2 \mathrm{~Hz}$, $\mathrm{H}-3), 4.42(1 \mathrm{H}, \mathrm{dd}, J=1.8,6.6 \mathrm{~Hz}, \mathrm{H}-4), 4.42(1 \mathrm{H}, \mathrm{dd}, J=6.6,7.2 \mathrm{~Hz}, \mathrm{H}-4), 1.95\left(3 \mathrm{H}, \mathrm{s}, 2-\mathrm{CH}_{3}\right), 4.24(1 \mathrm{H}$, d, $J=7.8 \mathrm{~Hz}$, glc-1), 4.49 5.07 (4H, br.s, glc-2, 3, 4, 6-OH), 2.94 3.67 (6H, m, glc-2, 3, 4, 5, 6); ${ }^{13} \mathrm{C}-\mathrm{NMR}$ (150 MHz, DMSO- $d_{6}$ ) $\delta: 118.1$ (C-1), 112.6 (C-2), 145.0 (C-3), 68.4 (C-4), 20.2 (C-5), 103.3 (C-1'), 74.0 $\left(\mathrm{C}-2^{\prime}\right), 77.6\left(\mathrm{C}-3^{\prime}\right), 70.6\left(\mathrm{C}-4^{\prime}\right), 77.4\left(\mathrm{C}-5^{\prime}\right), 61.6\left(\mathrm{C}-6^{\prime}\right)$.

Compound 5: white needles (MeOH), HR-ESI-TOF-MS: 451.1578 [M + Na] ${ }^{+}$(Calcd. for $\mathrm{C}_{20} \mathrm{H}_{28} \mathrm{O}_{10} \mathrm{Na}$ 451.1580, -0.4 ppm); ${ }^{1} \mathrm{H}-\mathrm{NMR}\left(600 \mathrm{MHz}, \mathrm{DMSO}-d_{6}\right) \delta: 7.43$ (2H, m, H-2, 6), 7.33 (2H, m, H-3, 5), 7.24 $(1 \mathrm{H}, \mathrm{m}, \mathrm{H}-4), 6.66(1 \mathrm{H}, \mathrm{d}, J=15.6 \mathrm{~Hz}, \mathrm{H}-7), 6.35(1 \mathrm{H}, \mathrm{dt}, J=16.2,5.4 \mathrm{~Hz}, \mathrm{H}-8), 4.40(1 \mathrm{H}, \mathrm{dd}, J=13.2$, $4.8 \mathrm{~Hz}, \mathrm{H}-9 \mathrm{a}), 4.20(1 \mathrm{H}, \mathrm{dd}, J=15.6,6.0 \mathrm{~Hz}, \mathrm{H}-9 \mathrm{~b}), 4.24\left(1 \mathrm{H}, \mathrm{d}, J=7.8 \mathrm{~Hz}\right.$, glc- $\left.1^{\prime}\right), 3.02 \sim 3.95(6 \mathrm{H}, \mathrm{m}$, glc-2' $\left.2^{\prime}, 4^{\prime}, 5^{\prime}, 6^{\prime}\right), 4.52\left(1 \mathrm{H}, \mathrm{d}, J=4.8 \mathrm{~Hz}\right.$, Ara- $\left.1^{\prime \prime}\right), 3.02 \sim 3.91\left(5 \mathrm{H}, \mathrm{m}\right.$, Ara- $\left.2^{\prime \prime}, 3^{\prime \prime}, 4^{\prime \prime}, 5^{\prime \prime}\right) ;{ }^{13} \mathrm{C}-\mathrm{NMR}$ $\left(150 \mathrm{MHz}, \mathrm{DMSO}-d_{6}\right) \delta: 136.7$ (C-1), $128.8(\mathrm{C}-2,6), 126.6$ (C-3, 5), $126.3(\mathrm{C}-4), 131.8$ (C-7), 127.8 (C-8), $68.8(\mathrm{C}-9), 102.1\left(\mathrm{C}-1^{\prime}\right), 73.7\left(\mathrm{C}-2^{\prime}\right), 76.8\left(\mathrm{C}-3^{\prime}\right), 70.6\left(\mathrm{C}-4^{\prime}\right), 75.7\left(\mathrm{C}-5^{\prime}\right), 67.4\left(\mathrm{C}-6^{\prime}\right), 108.8\left(\mathrm{C}-1^{\prime \prime}\right), 82.4$ $\left(\mathrm{C}-2^{\prime \prime}\right), 77.5\left(\mathrm{C}-3^{\prime \prime}\right), 84.0\left(\mathrm{C}-4^{\prime \prime}\right), 61.6\left(\mathrm{C}-5^{\prime \prime}\right)$.

Compound 6: white needles (MeOH), m.p. $170-172{ }^{\circ} \mathrm{C}$, HR-ESI-TOF-MS: $451.1583[\mathrm{M}+\mathrm{Na}]^{+}(\mathrm{Calcd}$. for $\left.\mathrm{C}_{20} \mathrm{H}_{28} \mathrm{O}_{10} \mathrm{Na} 451.1580,0.7 \mathrm{ppm}\right) ;{ }^{1} \mathrm{H}-\mathrm{NMR}\left(600 \mathrm{MHz}, \mathrm{DMSO}-d_{6}\right) \delta: 7.46(2 \mathrm{H}, \mathrm{m}, \mathrm{H}-2,6), 7.34$ $(2 \mathrm{H}, \mathrm{m}, \mathrm{H}-3,5), 7.24(1 \mathrm{H}, \mathrm{m}, \mathrm{H}-4), 6.68(1 \mathrm{H}, \mathrm{d}, J=15.6 \mathrm{~Hz}, \mathrm{H}-\alpha), 6.36(1 \mathrm{H}, \mathrm{dt}, J=16.2,6.0 \mathrm{~Hz}, \mathrm{H}-\beta)$, 4.20 4.23 (2H, dd, H- $\gamma), 4.58(1 \mathrm{H}, \mathrm{d}, J=15.6 \mathrm{~Hz}$, glc-1' $), 3.02-3.95\left(6 \mathrm{H}, \mathrm{m}\right.$, glc- $\left.2^{\prime}, 3^{\prime}, 4^{\prime}, 5^{\prime}, 6^{\prime}\right), 4.52(1 \mathrm{H}$, $\mathrm{d}, J=4.8 \mathrm{~Hz}$, Ara- $\left.{ }^{\prime \prime}\right), 3.02 \sim 3.95\left(5 \mathrm{H}, \mathrm{m}\right.$, Ara- $\left.2^{\prime \prime}, 3^{\prime \prime}, 4^{\prime \prime}, 5^{\prime \prime}\right) ;{ }^{13} \mathrm{C}-\mathrm{NMR}\left(150 \mathrm{MHz}\right.$, DMSO- $\left.d_{6}\right) \delta: 136.5$ (C-1), $128.6(\mathrm{C}-2,6), 127.6(\mathrm{C}-3,5), 126.3(\mathrm{C}-4), 131.5(\mathrm{C}-\alpha), 126.2(\mathrm{C}-\beta), 68.5(\mathrm{C}-\gamma), 101.9\left(\mathrm{C}-1^{\prime}\right), 73.4$ $\left(\mathrm{C}-2^{\prime}\right), 76.6\left(\mathrm{C}-3^{\prime}\right), 70.2\left(\mathrm{C}-4^{\prime}\right), 75.7\left(\mathrm{C}-5^{\prime}\right), 64.9\left(\mathrm{C}-6^{\prime}\right), 103.5\left(\mathrm{C}-1^{\prime \prime}\right), 72.5\left(\mathrm{C}-2^{\prime \prime}\right), 70.5\left(\mathrm{C}-3^{\prime \prime}\right), 68.1\left(\mathrm{C}-4^{\prime \prime}\right)$, $67.3\left(\mathrm{C}-5^{\prime \prime}\right)$. 
Compound 7: yellow powder $(\mathrm{MeOH})$, m.p. 232.8-235.9 ${ }^{\circ} \mathrm{C}$, HR-ESI-TOF-MS: $449.1085[\mathrm{M}+\mathrm{H}]^{+}$ (Calcd. for $\mathrm{C}_{21} \mathrm{H}_{21} \mathrm{O}_{11}$ 449.1084, 0.2 ppm); ${ }^{1} \mathrm{H}-\mathrm{NMR}\left(600 \mathrm{MHz}, \mathrm{CD}_{3} \mathrm{OD}\right) \delta: 11.92$ (1H, s, 5-OH), 8.12 $\left(2 \mathrm{H}, \mathrm{d}, J=9.0 \mathrm{~Hz}, \mathrm{H}-2^{\prime}, 6^{\prime}\right), 6.92\left(2 \mathrm{H}, \mathrm{d}, J=8.4 \mathrm{~Hz}, \mathrm{H}-3^{\prime}, 5^{\prime}\right), 7.05(1 \mathrm{H}, \mathrm{s}, \mathrm{H}-6), 5.56(1 \mathrm{H}, \mathrm{d}, J=1.2 \mathrm{~Hz}$, rha-1), $7.05(1 \mathrm{H}, \mathrm{s}$, rha-2-OH), $6.74(2 \mathrm{H}, \mathrm{d}$, rha-3-OH), $6.42(2 \mathrm{H}, \mathrm{d}$, rha-4-OH), $3.84(1 \mathrm{H}, \mathrm{m}, \mathrm{rha}-2), 4.02$ $\left(1 \mathrm{H}, \mathrm{m}\right.$, rha-3), 3.49 (1H, m, rha-4), $3.61\left(1 \mathrm{H}, \mathrm{m}\right.$, rha-5); ${ }^{13} \mathrm{C}-\mathrm{NMR}\left(150 \mathrm{MHz}, \mathrm{CD}_{3} \mathrm{OD}\right) \delta: 147.5$ (C-2), 135.8 (C-3), 176.4 (C-4), 150.1 (C-5), 98.3 (C-6), 151.6 (C-7), 127.1 (C-8), 144.5 (C-9), 104.5 (C-10), 121.8 $\left(\mathrm{C}-1^{\prime}\right), 129.8\left(\mathrm{C}-2^{\prime}, 6^{\prime}\right), 159.3\left(\mathrm{C}-4^{\prime}\right), 115.4\left(\mathrm{C}-3^{\prime}, 5^{\prime}\right), 99.4$ (rha-1), 70.0 (rha-2), 69.9 (rha-3), 71.7 (rha-4), 69.9 (rha-5), 17.9 (rha-6).

\subsection{Molecular Docking}

Seven molecular compounds were selected as ligands among the small compounds targeting fibroblast activation protein- $\alpha$ (FAP- $\alpha)$. We downloaded the initial three-dimensional (3D) geometric coordinates of the X-ray crystal structures of the compounds and proteins from the Protein Data Bank [38], and the chemical structures of the candidate compounds were drawn using ChemDraw software ver. 12.0 [39]. The 3D FAP- $\alpha$ protein structure (PDB ID: 1Z68) interacted with the candidate compounds. Molecular docking was performed using the UCSF DOCK6.5 program [40]. The DOCK algorithm addresses rigid body docking by superimposing the ligand onto a negative image of the binding pocket.

\subsection{Statistical Analysis}

All quantitative data are expressed as mean \pm standard deviation. Data were analyzed using SPSS 17.0 software (SPSS Inc., Chicago, IL, USA). One-way analysis of variance was used to detect differences among the groups. A $p$-value $<0.05$ was considered significant.

\section{Conclusions}

In summary, RRL had prophylactic and therapeutic effects on BLM-induced PF in rats, which were related to its anti-inflammatory and anti-oxidative properties. RRL may reduce the expression and activities of MMP-9 and $\alpha$-SMA. Further study is necessary to elucidate the mechanisms of how RRL reduced MMP-9 expression and activity.

Acknowledgments: The authors gratefully acknowledge financial support from the Liaoning Science and Technology Project (2013226027-4), the National Natural Science Foundation (30960493), Key Projects of the National Science and Technology Pillar Program (2012BAI30B02), and Shenyang Pharmaceutical University College Student's Innovation and Entrepreneurship Training Program. The authors thank Yong Tan for identifying the Rhodiola rosea L. plants.

Author Contributions: Ke Zhang, Jian Huang, Guo-Yu Li and Jin-Hui Wang conceived and designed the research. Ke Zhang, Xiao-Ping Si, Jian Han, Xu Liang, Xiao-Bo Xu, Yi-Ting Wang and Hang-Yu Wang performed the experiments; Ke Zhang, Jian Huang, and Jin-Hui Wang analyzed the data and prepared the paper; Ke Zhang, Jian Huang and Jin-Hui Wang wrote the manuscript; And Jin-Hui Wang revised the paper.

Conflicts of Interest: The authors declare no conflict of interest.

\section{References}

1. Calabrese, F.; Kipar, A.; Lunardi, F.; Balestro, E.; Perissinotto, E.; Rossi, E.; Nannini, N.; Marulli, G.; Stewart, J.P.; Rea, F. Herpes virus infection is associated with vascular remodeling and pulmonary hypertension in idiopathic pulmonary fibrosis. PLoS ONE 2013, 8, e55715. [CrossRef] [PubMed]

2. Higashiyama, H.; Yoshimoto, D.; Kaise, T.; Matsbara, S.; Fujiwara, M.; Kikkawa, H.; Asano, S.; Kinoshita, M. Inhibition of activin receptor-like kinase 5 attenuates bleomycin-induced pulmonary fibrosis. Exp. Mol. Pathol. 2007, 83, 39-46. [CrossRef] [PubMed]

3. Tan, S.Z.; Liu, C.H.; Zhang, W.; Lu, X.; Ye, W.C.; Cai, Z.Z.; Liu, P. Feature changes of MMP-2/9 activities and TIMP-1/2 protein expressions during the progression of pulmonary fibrosis in rats. J. Chin. Integr. Med. 2006, 4, 402-407. [CrossRef] 
4. Smith, R.E.; Strieter, R.M.; Phan, S.H.; Lukacs, N.; Kunkel, S.L. TNF and IL-6 mediate MIP-1 $\alpha$ expression in bleomycin-induced lung injury. J. Leukoc. Biol. 1998, 64, 528-536. [PubMed]

5. Oikonomou, N.; Harokopos, V.; Zalevsky, J.; Valavanis, C.; Kotanidou, A.; Szymkowski, D.E.; Kollias, G.; Aidinis, V. Soluble TNF mediates the transition from pulmonary inflammation to fibrosis. PLoS ONE 2006, 1, e108. [CrossRef] [PubMed]

6. Beeh, K.M.; Beier, J.; Kornmann, O.; Buhl, R. Sputum matrix metalloproteinase-9, tissue inhibitor of metalloprotinease-I, and their molar ratio in patients with chronic obstructive pulmonary disease, idiopathic pulmonary fibrosis and healthy subjects. Respir. Med. 2003, 97, 634-639. [CrossRef] [PubMed]

7. Chung, K.F. Inflammatory mediators in chronic obstructive pulmonary disease. Curr. Drug Targets Inflamm. Allergy 2005, 4, 619-625. [CrossRef] [PubMed]

8. John, M.; Oltmanns, U.; Fietze, I.; Witt, C.; Jung, K. Increased production of matrix metalloproteinase-2 in alveolar macrophages and regulation by interleukin-10 in patients with acute pulmonary sarcoidosis. Exp. Lung Res. 2002, 28, 55-68. [CrossRef] [PubMed]

9. Sasaki, M.; Kashima, M.; Ito, T.; Watanabe, A.; Izumiyama, N.; Sano, M.; Kagaya, M.; Shioya, T.; Miura, M. Differential regulation of metalloproteinase production, proliferation and chemotaxis of human lung fibroblasts by PDGF, interleukin-1 $\beta$ and TNF- $\alpha$. Mediat. Inflamm. 2000, 9, 155-160. [CrossRef] [PubMed]

10. Saratikov, A.S.; Krasnov, E.A. Rhodiola rosea (Golden Root), 4th ed.; Tomsk State University Publishing House: Tomsk, Russia, 2004; pp. 22-41.

11. Schriner, S.E.; Avanesian, A.; Liu, Y.; Luesch, H.; Jafari, M. Protection of human cultured cells against oxidative stress by Rhodiola rosea without activation of antioxidant defenses. Free Radic. Biol. Med. 2009, 47, 577-584. [CrossRef] [PubMed]

12. Diermen, D.V.; Marsto, A.; Bravo, J.; Reist, M.; Carrupt, P.A.; Hostettmann, K. Monoamine oxidase inhibition by Rhodiola rosea L. roots. J. Ethnopharmacol. 2009, 122, 397-401. [CrossRef] [PubMed]

13. Panossian, A.; Wikman, G.; Sarris, J. Rosenroot (Rhodiola rosea): Traditional use, chemical composition, pharmacology and clinical efficacy. Phytomedicine 2010, 17, 481-493. [CrossRef] [PubMed]

14. Chen, A.Y.; Chen, Y.C. A review of the dietary flavonoid, kaempferol on human health and cancer chemoprevention. Food Chem. 2013, 138, 2099-2107. [CrossRef] [PubMed]

15. Qiao, Y.; Xiang, Q.; Yuan, L.; Xu, L.; Liu, Z.; Liu, X. Herbacetin induces apoptosis in HepG2 cells: Involvements of ROS and PI3K/Akt pathway. Food Chem. Toxicol. 2013, 51, 426-433. [CrossRef] [PubMed]

16. Díaz, L.A.M.; Abad, M.M.J.; Fernández, M.L.; Recuero, C.C.; Villaescusa, C.L.; Silván, S.A.M.; Bermejo, B.P. Lignan and phenyl propanoid glycosides from Phillyrea latifolia and their in vitro anti-inflammatory activity. Planta Med. 2001, 67, 219-223. [CrossRef]

17. Doncheva, N.D.; Mihaylova, A.S.; Getova, D.P. Antinociceptive and anti-inflammatory effects of Rhodiola rosea L. Extract in rats. Folia Med. 2013, 55, 70-75. [CrossRef]

18. Tang, H.; Gao, L.; Mao, J.; He, H.; Liu, J.; Cai, X.; Lin, H.; Wu, T. Salidroside protects against bleomycin-induced pulmonary fibrosis: Activation of Nrf2-antioxidant signaling, and inhibition of NF- $\mathrm{kB}$ and TGF- $\beta 1 /$ Smad-2/-3 pathways. Cell Stress Chaperones 2015, 11, 1-11. [CrossRef] [PubMed]

19. Sener, G.; Topaloglu, N.; Sehirli, A.O.; Ercan, F.; Gedik, N. Resveratrol alleviates bleomycin-induced lung injury in rats. Pulm. Pharmacol. Ther. 2007, 20, 642-649. [CrossRef] [PubMed]

20. Letterio, J.J.; Roberts, A.B. Regulation of immune responses by TGF- $\beta$. Annu. Rev. Immunol. 1998, 16, $137-161$. [CrossRef] [PubMed]

21. Assoian, R.K.; Fleurdelys, B.E.; Stevenson, H.C.; Miller, P.J.; Madtes, D.K.; Raines, E.W.; Ross, R.; Sporn, M.B. Expression and secretion of type $\beta$ transforming growth factor by activated human macrophages. Proc. Natl. Acad. Sci. USA 1987, 84, 6020-6024.

22. Grotendorst, G.R.; Smale, G.; Pencev, D. Production of transforming growth factor $\beta$ by human peripheral blood monocytes and neutrophils. J. Cell. Physiol. 1989, 140, 396-402. [CrossRef] [PubMed]

23. Thrall, R.S.; McCormick, J.R.; Jack, R.M.; McReynolds, R.A.; Ward, P.A. Bleomycin-induced pulmonary fibrosis in the rat: Inhibition by indomethacin. Am. J. Pathol. 1979, 95, 117-130. [PubMed]

24. Claussen, C.A.; Long, E.C. Nucleic acid recognition by metal complexes of bleomycin. Chem. Rev. 1999, 99, 2797-2816. [CrossRef] [PubMed]

25. Blaisdell, R.J.; Giri, S.N. Mechanism of antifibrotic effect of taurine and niacin in the multidose bleomycin-hamster model of lung fibrosis: Inhibition of lysyl oxidase and collagenase. J. Biochem. Toxicol. 1995, 10, 203-210. [CrossRef] [PubMed] 
26. Balestrini, J.; Chaudhry, S.; Sarrazy, V.; Hinz, B. The mechanical memory of lung myofibroblasts. Integr. Biol. 2012, 4, 410-421. [CrossRef] [PubMed]

27. Tanjore, H.; Xu, X.C.; Polosukhin, V.V.; Degryse, A.L.; Li, B.; Han, W.; Sherrill, T.P.; Plieth, D.; Neilson, E.G.; Blackwell, T.S.; et al. Contribution of epithelial-derived fibroblasts to bleomycin-induced lung fibrosis. Am. J. Respir. Crit. Care Med. 2009, 180, 657-665. [CrossRef] [PubMed]

28. Tang, H.; He, H.; Ji, H.; Gao, L.; Mao, J.; Liu, J.; Lin, H.; Wu, T. Tanshinone IIA ameliorates bleomycin-induced pulmonary fibrosis and inhibits transforming growth factor-beta- $\beta$-dependent epithelial to mesenchymal transition. J. Surg. Res. 2015, 197, 167-175. [CrossRef] [PubMed]

29. Qu, Y.; Zhang, L.; Kang, Z.; Jiang, W.; Lv, C. Ponatinib ameliorates pulmonary fibrosis by suppressing TGF- $31 /$ Smad3 pathway. Pulm. Pharmacol. Ther. 2015, 34, 1-7. [CrossRef] [PubMed]

30. Degryse, A.L.; Tanjore, H.; Xu, X.C.; Polosukhin, V.V.; Jones, B.R.; McMahon, F.B.; Gleaves, L.A.; Blackwell, T.S.; Lawson, W.E. Repetitive intratracheal bleomycin models several features of idiopathic pulmonary fibrosis. Am. J. Physiol. Lung Cell. Mol. Physiol. 2010, 299, 442-452. [CrossRef] [PubMed]

31. Pera, T.; Zuidhof, A.; Valadas, J.; Smit, M.; Schoemaker, R.G.; Gosens, R.; Maarsingh, H.; Zaagsma, J.; Meurs, H. Tiotropium inhibits pulmonary inflammation and remodelling in a guinea pig model of COPD. Eur. Respir. J. 2011, 38, 789-796. [CrossRef] [PubMed]

32. Zhu, B.; Ma, A.Q.; Yang, L.; Dang, X.M. Atorvastatin attenuates bleomycin-induced pulmonary fibrosis via suppressing iNOS expression and the CTGF (CCN2)/ERK signaling pathway. Int. J. Mol. Sci. 2013, 14, 24476-24491. [CrossRef] [PubMed]

33. Lee, M.W.; Lee, Y.A.; Park, H.M.; Toh, S.H.; Lee, E.J.; Jang, H.D.; Kim, Y.H. Antioxidative phenolic compounds from the roots of Rhodiolasachalinensis A. Bor. Arch. Pharm. Res. 2000, 23, 455-458. [CrossRef] [PubMed]

34. Zhang, K.; Li, G.Y.; Wang, H.Y.; Meng, H.; Xie, S.A.; Gao, J.B.; Wang, J.H. Study on the flavonoids constituents of Rhodiola Rosea L. Mod. Chin. Med. 2010, 12, 20-23.

35. Zapesochnaya, G.G.; Kurkin, V.A. Glycosides of cinnamyl alcohol from the rhizomes of Rhodiolarosea. Chem. Nat. Compd. 1982, 18, 685-688. [CrossRef]

36. Yoshikawa, M.; Shimada, H.; Shimoda, H.; Murakami, N.; Yamahara, J.; Matsuda, H. Development of bioactive functions in hydrangeae dulcis folium. V. On the antiallergic and antimicrobial principles of hydrangeae dulcis folium. (2). Thunberginols $\mathrm{C}, \mathrm{D}$, and E, thunberginol G 3'-O-glucoside, (-)-hydrangenol 4'-O-glucoside, and (+)-hydrangenol 4'-O-glucoside. Chem. Pharm. Bull. 1996, 44, 2086-2091. [PubMed]

37. Comte, G.; Chulia, A.J.; Vercauteren, J.; Allais, D.P. Phenylpropane glycosides from Juniperus phoenicea. Planta Med. 1996, 62, 88-89. [CrossRef] [PubMed]

38. Protein Data Bank (PDB), Research Collaboratory for Structural Bioinformatics, New York, NY, USA. Available online: http://www.pdb.org/pdb/home/home.do (accessed on 29 December 2015).

39. Chem3D Ultra12.0, Cambridge Soft Corporation, Cambridge, MA, USA. Available online: http:// chembiodraw-ultra.software.informer.com/13.0/ (accessed on 27 December 2015).

40. UCSF DOCK6.5 Program. Regents of the University of California All Rights Reserved, San Francisco, CA, USA, 2015.

(C) 2016 by the authors; licensee MDPI, Basel, Switzerland. This article is an open access article distributed under the terms and conditions of the Creative Commons Attribution (CC-BY) license (http://creativecommons.org/licenses/by/4.0/). 